\title{
Spatial distribution of modern dinoflagellate cysts in polluted estuarine sediments from Buzzards Bay (Massachusetts, USA) embayments
}

\author{
Vera Pospelova ${ }^{1,2, *}$, Gail L. Chmura ${ }^{1}$, Warren S. Boothman ${ }^{3}$, James S. Latimer ${ }^{3}$ \\ ${ }^{1}$ Department of Geography and Centre for Climate and Global Change Research, McGill University, \\ 805 Sherbrooke Street West, Montreal, Quebec H3A 2K6, Canada \\ ${ }^{2}$ School of Earth and Ocean Sciences, University of Victoria, Petch 168, PO Box 3055 STN CSC, Victoria, \\ British Columbia V8W 3P6, Canada \\ ${ }^{3}$ US Environmental Protection Agency, Office of Research and Development, NHEERL, Atlantic Ecology Division, \\ Narragansett, Rhode Island 02882, USA
}

\begin{abstract}
Analysis of the spatial distribution of the dinoflagellate cyst assemblages in 19 surface sediment samples collected from 3 Buzzards Bay (Massachusetts, USA) embayments revealed the potential applicability of dinoflagellate cysts as biological indicators of environmental conditions in estuarine systems. Sites with the highest levels of toxic pollution and hypertrophic conditions are characterized by the lowest dinoflagellate cyst species-richness and concentrations. Among the abiotic factors influencing the distribution of dinoflagellate cysts, nutrients and toxic pollution are the major controls, as in these embayments salinity and temperature variability is low. Principal component analysis, based on the proportions of cyst taxa, indicated that cyst assemblages gradually change when moving away from the sources of nutrient pollution, sewage outfalls in particular.
\end{abstract}

KEY WORDS: Dinoflagellate cyst · Eutrophication $\cdot$ Heavy metals $\cdot$ Sewage $\cdot$ Wastewater treatment plant $\cdot$ PCBs $\cdot$ Apponagansett Bay $\cdot$ New Bedford Harbor

\section{INTRODUCTION}

Human activities such as nutrient enrichment and toxic pollution cause water-quality degradation and habitat loss. These activities are most intensive in estuaries with highly urbanized and industrialized watersheds. Concern about water-quality degradation in estuarine waters has stimulated a demand for development of indicators of nutrient enrichment and toxic contamination to examine paleo- and modern environmental conditions and trends caused by intensified anthropogenic activities in watersheds.

To be a useful biological indicator of environmental conditions, an organism has to satisfy certain criteria (Gibson et al. 2000). In general, a biological indicator should be ubiquitous, well preserved in sediments, numerous enough for statistical treatment, and reflect certain environmental parameters. Dinoflagellate cysts have proven to satisfy all the above criteria (Fensome et al. 1996).

Dinoflagellates are single-celled organisms that constitute an important part of the phytoplankton population in aquatic ecosystems. During their life cycle some dinoflagellates produce hypnozygotes, or resting cysts, which can be preserved in sediments (Fensome et al. 1993). The assemblages of dinoflagellate cysts in sediments encode information on the dinoflagellates in the upper water column (Dale 1976, Reid \& Harland 1978). In turn, the population of dinoflagellates is influenced by environmental factors such as temperature and salinity, nutrients, turbidity and pollution (Taylor 1987). Dinoflagellate cysts recovered from coastal sediments have the potential to provide substantial information on biological processes and interactions within aquatic systems.

Several studies have examined the temporal development of estuarine eutrophication and pollution by 
analyzing the dinoflagellate cyst records in sediment cores (Dale \& Fjellså 1994, Sætre et al. 1997, Thorsen \& Dale 1997, Dale et al. 1999, Matsuoka 1999, 2001, Dale 2001, Pospelova et al. 2002). A recent study of the historical records of dinoflagellate cysts from shallow unstratified embayments of Buzzards Bay (New Bedford Harbor and Apponagansett Bay) found that species richness (number of taxa), total cyst concentrations and fluxes, proportions of some heterotrophic species, as well as abundance of indicator species changed as a result of eutrophication and toxic pollution (Pospelova et al. 2002). In oligotrophic systems, such as New Bedford Harbor in its early history (Pospelova et al. 2002), nutrient enrichment initially increases dinoflagellate cyst species-richness. However, under highly eutrophic and polluted conditions, species diversity declines, as seen during the 20th century in New Bedford Harbor. These extreme conditions are also characterized by large fluctuations in total cyst concentrations and fluxes. The proportion of cysts of heterotrophic dinoflagellates, Polykrikaceae and Diplopsalidaceae in particular, tends to increase with increasing nutrient enrichment.

If the dinoflagellate cyst record reflects the temporal changes of the environmental conditions in an estuary, it must also show spatial change, as environmental conditions in an estuary are non-uniform. If so, dinoflagellate cyst assemblages from surface samples can be used to support or discard some of the conclusions previously made about the 'eutrophication and pollution signals' drawn from analyses of dinoflagellate cysts in the cores. No previous studies have investigated spatial distributions of dinoflagellate cysts in relation to eutrophication and toxic pollution in estuarine systems. This work represents the first analysis of this kind.

In this study we document the dinoflagellate cyst assemblages on a $\sim 1 \mathrm{~km}$ scale in 3 side embayments of Buzzards Bay, Massachusetts. Comparison of these assemblages to known gradients of nutrient and toxic pollution allows us to assess the utility of cysts as indicators of plankton response.

\section{MATERIAL AND METHODS}

Study area. New Bedford Harbor, Clarks Cove and Apponagansett Bay are side embayments of the northwestern shore of Buzzards Bay, Massachusetts, USA (Fig. 1). The embayments are shallow, with water depths ranging from 1 to $12 \mathrm{~m}$ (mean $6 \mathrm{~m}$ ), generally well mixed, and unstratified. There are no major bottom currents in Buzzards Bay, and most of the environmental energy is in tidal currents and waves (Summerhayes et al. 1985). The

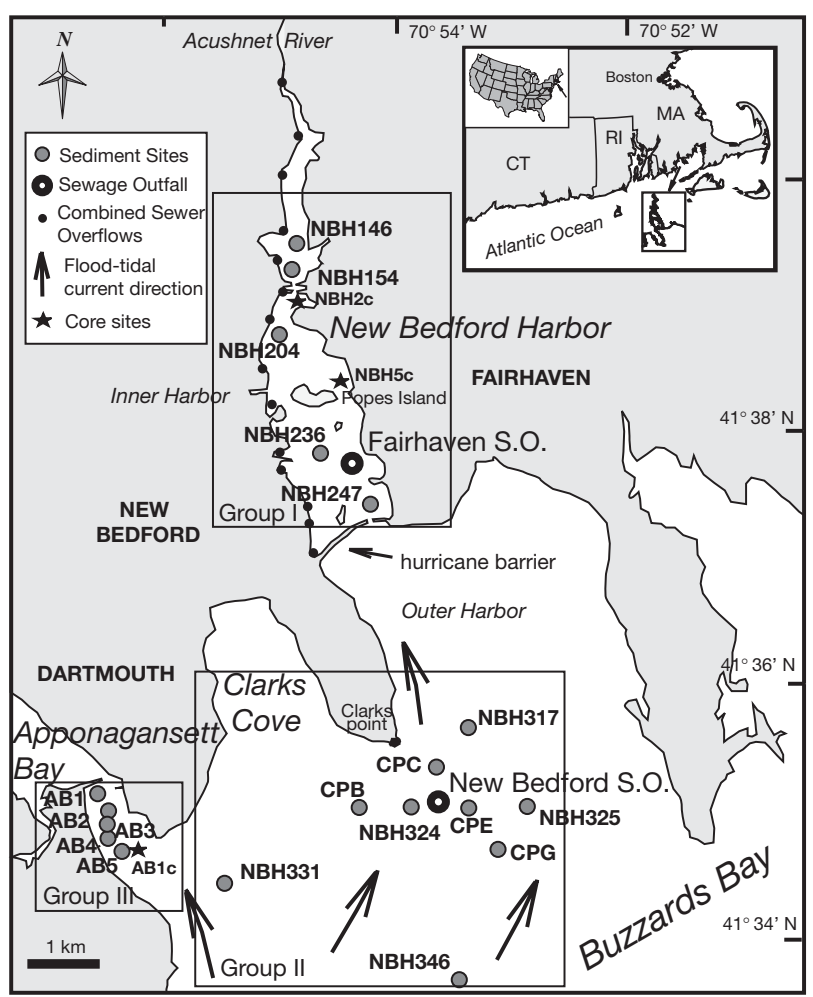

Fig. 1. New Bedford Harbor, Clarks Cove and Apponagansett Bay showing location of surface sediment samples. Direction of tidal-flood current from Howes et al. (1996), locations of 3 core sites from Pospelova et al. (2002)

tidal range is about $1 \mathrm{~m}_{i}$ the direction of tidal-flood current is shown in Fig. 1.

Mean summer (June, July and August) water salinity varies from 28 to 31 and summer temperatures from 21 to $23^{\circ} \mathrm{C}$ (Howes et al. 1999). Concentrations of nutrients and chlorophyll $a$ for the studied embayments are provided in Table 1. Ammonium is the major form of inorganic nitrogen available throughout the Bay and its concentrations are heavily influenced by the sewage outfall (Borkman \& Turner 1993). A study of economic growth and environmental change in Buzzards Bay (Terkla et al. 1990) has identified population growth as the dominant factor currently affecting the environmental health of Buzzards Bay.

New Bedford Harbor: New Bedford Harbor, also known as the Acushnet River estuary, has a moderate

Table 1. Comparison of mean summer (June to August) concentrations of nutrients and chlorophyll $a$ in embayments of Buzzards Bay

\begin{tabular}{|lrccc|}
\hline Location & $\begin{array}{c}\text { Nitrate } \\
(\mu \mathrm{M})\end{array}$ & $\begin{array}{c}\text { Ammonium } \\
(\mu \mathrm{M})\end{array}$ & $\begin{array}{c}\text { Phosphate } \\
(\mu \mathrm{M})\end{array}$ & $\begin{array}{c}\text { Chlorophyll } a \\
\left(\mu \mathrm{g} \mathrm{l}^{-1}\right)\end{array}$ \\
\hline Inner New Bedford Harbor & 11.0 & 5.7 & 1.8 & 8.5 \\
Clarks Cove & 1.5 & 0.9 & 1.5 & 3.7 \\
Apponagansett Bay & 1.3 & 2.2 & 1.6 & 4.7 \\
\hline
\end{tabular}


freshwater input (median flow $0.54 \mathrm{~m}^{3} \mathrm{~s}^{-1}$ ) from the river flowing into the northern part of the harbor. This harbor is heavily urbanized, as it is surrounded by $35 \%$ of the population of the entire Buzzards Bay watershed (Howes et al. 1999). As a result, 20 combined sewer overflows (CSO) discharge into the inner part of New Bedford Harbor, in addition to the outfall of the Fairhaven Wastewater Treatment Plant (Fig. 1). From 1974 to 1996, the Fairhaven facility has continuously discharged primary-treated sewage to the harbor, resulting in a load of $140 \mathrm{t} \mathrm{N} \mathrm{yr}^{-1}$ (SAIC 1991). A hurricane barrier greatly reduces water circulation relative to the rest of Buzzards Bay and affects water quality (Costa et al. 1996). Based on Nixon's (1995) classification, the inner New Bedford Harbor is a 'hypertrophic' or highly eutrophic system, and is one of the most eutrophic embayments in Buzzards Bay (Howes et al. 1999).

New Bedford Harbor also is one of the most contaminated sites in the United States (Nelson et al. 1996) due to polychlorinated biphenyls (PCBs) used in the manufacture of electrical capacitors. Past discharges of PCBs and other pollutants in the upper harbor have resulted in modern sediment concentrations as high as $35000 \mathrm{ng} \mathrm{g}^{-1} \mathrm{PCBs}, 1500 \mu \mathrm{g} \mathrm{g}^{-1} \mathrm{Cu}, 600 \mu \mathrm{g} \mathrm{g}^{-1} \mathrm{~Pb}$, and $1200 \mathrm{\mu g} \mathrm{g}^{-1} \mathrm{Zn}$. New Bedford Harbor is listed in the US Environmental Protection Agency's National Priorities List for cleanup because of PCBs contamination (Bergen et al. 1998).

New Bedford's outer harbor, south of the hurricane barrier (Fig. 1), is expansive and well-flushed. The primary difference between the outer and inner harbor is a lower sedimentary concentration of PCBs, heavy metals and other industrial pollutants in the former. However, the surface plume of effluent from the New Bedford Wastewater Treatment Facility, located off Clarks Point, influences local water-quality conditions. The New Bedford Wastewater Treatment Plant discharges up to $962 \mathrm{t} \mathrm{N} \mathrm{yr}^{-1}$ into the system, mostly in the form of ammonium (SAIC 1991). Elevated concentrations of nitrate $(1.2 \mu \mathrm{M})$, ammonium $(16.4 \mu \mathrm{M})$, and phosphorus $(3.0 \mu \mathrm{M})$ were measured near the outfall by Borkman \& Turner (1993). Despite the high sewage-effluent input, effects of the discharge on water quality are detectable only within $5 \mathrm{~km}$ of the outfall (Costa et al. 1999).

Apponagansett Bay: Similar to New Bedford Harbor, inner Apponagansett Bay is one of the most eutrophic embayments of Buzzards Bay because of its restricted geomorphology and nutrient loading from the watershed (Howes et al. 1999). The high nutrient load to the estuary originates mostly from its densely populated watershed, followed by commercial and industrial development. In contrast to the inner bay, the outer Apponagansett Bay is better flushed, with moderate nutrient levels (Howes et al. 1999).
Clarks Cove: In contrast to New Bedford Harbor, the neighboring Clarks Cove (Fig. 1) has relatively good water quality because of the absence of major freshwater sources and a sewered watershed, with discharges located at Clarks Point (New Bedford Wastewater Treatment Plant). Clarks Cove water quality is maintained primarily by its tidal dynamics (Howes et al. 1999). Despite the fact that Clarks Cove is a comparatively deep ( 9 $\mathrm{m})$ and well-flushed embayment, the total nitrogen level here is higher than in the waters of outer Buzzards Bay. This enrichment of Clarks Cove waters comes from the Clarks Point outfall when its waters enter the system during periodic shifts in the outer harbor circulation, and from the tidal waters of Apponagansett Bay to the west (Howes et al. 1999).

Sample collection. Surface sediments were collected from 19 locations throughout New Bedford Harbor, Clarks Cove and Apponagansett Bay (Fig. 1, Table 2). For the purpose of this study, we divide all samples into 3 groups (Table 2), based on their location: Group I comprised 5 samples from the inner part of New Bedford Harbor, Group II comprised 9 samples from the outer harbor and Clarks Cove, and Group III comprises 5 samples from the outer part of Apponagansett Bay.

Sediments were collected with a van Veen or petite Ponar grab sampler during the US Environmental Protection Agency (EPA) cruises in October 1996. All samples were stored at $\sim 4^{\circ} \mathrm{C}$ in the dark until processing in 1999. We assume that the top $2 \mathrm{~cm}$ of collected sediments represent $\sim 10$ yr deposition, based on the estimates of accumulation rates previously reported for the embayments (Summerhayes et al. 1985, Latimer et al. 2003). Sediments are generally characterized as fine sand and mud (Table 2).

Sediment chemistry. Sedimentary metal concentrations were measured by inductively-coupled plasma atomic-emission and graphite furnace atomic-absorption spectrophotometry after digestion by microwave heating in pressurized digestion vessels with a mixture of concentrated acids (for details see Latimer et al. 2003). PCBs were extracted using a microwave procedure and analyzed using gas chromatography with electron-capture detector (for details see Latimer et al. 2003). Percent organic carbon was measured by continuous-flow elemental analysis/isotope-ratio massspectrometry as described by Latimer et al. (2003).

Dinoflagellate cysts. For dinoflagellate cyst analyses, sediment samples of known volume and dry weight were processed using standard palynological preparation methods (Rochon et al. 1999). Sediment was dried at $40^{\circ} \mathrm{C}$, weighed, sieved through $125 \mu \mathrm{m}$ mesh and retained on a $10 \mu \mathrm{m}$ mesh (to eliminate coarse and fine material), treated with warm $\mathrm{HF}(40 \%)$ to dissolve silicates, and $\mathrm{HCl}(10 \%)$ to remove carbonates and silicofluorides. Calibrated tablets of Lycopodium clavatum spores 
Table 2. Surface sediment samples. Collection data

\begin{tabular}{|c|c|c|c|c|c|c|}
\hline $\begin{array}{l}\text { Group } \\
\text { Station ID }\end{array}$ & Location & $\begin{array}{l}\text { Latitude } \\
\qquad\left({ }^{\circ} \mathrm{N}\right)\end{array}$ & $\begin{array}{c}\text { Longitude } \\
\left({ }^{\circ} \mathrm{W}\right)\end{array}$ & $\begin{array}{l}\text { Water depth } \\
\text { (m) }\end{array}$ & $\begin{array}{l}\text { Sediment } \\
\text { type }\end{array}$ & $\begin{array}{l}\text { Sampling } \\
\text { method }\end{array}$ \\
\hline \multicolumn{7}{|l|}{ Group I } \\
\hline NBH146 & New Bedford Harbor (inner) & 41.660 & 70.917 & 4.6 & Sandy silt & Petite Ponar \\
\hline NBH154 & New Bedford Harbor (inner) & 41.657 & 70.918 & 7.3 & Sandy silt & Petite Ponar \\
\hline NBH204 & New Bedford Harbor (inner) & 41.652 & 70.920 & 4 & Sandy silt & Petite Ponar \\
\hline NBH236 & New Bedford Harbor (inner) & 41.634 & 70.913 & 9.8 & Mud & Petite Ponar \\
\hline NBH247 & New Bedford Harbor (inner) & 41.627 & 70.905 & 3 & Sandy silt & Petite Ponar \\
\hline \multicolumn{7}{|l|}{ Group II } \\
\hline NBH324 & Clarks Cove/New Bedford Harbor (outer) & 41.582 & 70.899 & $\sim 9$ & Sandy silt & Petite Ponar \\
\hline CPE & Clarks Cove/New Bedford Harbor (outer) & 41.582 & 70.890 & 9 & Mud & Petite Ponar \\
\hline $\mathrm{CPC}$ & Clarks Cove/New Bedford Harbor (outer) & 41.588 & 70.895 & 9 & Fine sand & Petite Ponar \\
\hline $\mathrm{CPB}$ & Clarks Cove/New Bedford Harbor (outer) & 41.582 & 70.907 & 9.6 & Mud & Petite Ponar \\
\hline CPG & Clarks Cove/New Bedford Harbor (outer) & 41.576 & 70.886 & 8.8 & Mud & Petite Ponar \\
\hline NBH317 & New Bedford Harbor (outer) & 41.594 & 70.890 & 9.8 & Sandy silt & Petite Ponar \\
\hline NBH325 & New Bedford Harbor (outer) & 41.582 & 70.881 & $\sim 10$ & Sandy silt & Petite Ponar \\
\hline NBH346 & Buzzards Bay & 41.545 & 70.891 & $\sim 10$ & Mud & Petite Ponar \\
\hline NBH331 & Clarks Cove/Apponagansett Bay & 41.570 & 70.928 & 7.5 & Mud & Petite Ponar \\
\hline \multicolumn{7}{|l|}{ Group III } \\
\hline AB1 & Apponagansett Bay & 41.584 & 70.948 & 2.4 & Sandy silt & Van Veen \\
\hline AB2 & Apponagansett Bay & 41.581 & 70.947 & 4.6 & Sandy silt & Van Veen \\
\hline AB3 & Apponagansett Bay & 41.580 & 70.947 & 5.2 & Silt & Van Veen \\
\hline AB4 & Apponagansett Bay & 41.578 & 70.947 & 5.2 & Sandy silt & Van Veen \\
\hline AB5 & Apponagansett Bay & 41.576 & 70.945 & 4.9 & Sandy silt & Van Veen \\
\hline
\end{tabular}

(Stockmarr 1977), added during processing, allowed calculation of dinoflagellate cyst concentrations. In this study, we express dinoflagellate cyst concentrations in 2 units: cysts per volume of wet sediments, and cysts per dry weight of sediments. Cyst concentrations based on dry weight of sediments facilitate comparison with core studies, whereas concentrations based on volume are often applied to study spatial cyst distributions.

Aliquots were mounted on microscope slides with glycerine jelly. Dinoflagellate cysts were counted with a transmitted light microscope (63× and $100 \times$ objectives). Identification of dinoflagellate cysts was made on the basis of published descriptions in accordance with taxonomy given by Lentin \& Williams (1993) and Rochon et al. (1999). However, when species-level identification was not possible, identification was to genus level. There are different taxonomies for cysts and thecal stages of dinoflagellates because paleontological studies of cysts originally were carried out independently from biological studies of the motile forms. Here we use the paleontological nomenclature according to Head (1996), Head et al. (2001), and Pospelova \& Head (2002). A list of the dinoflagellate cysts counted and their known biological name or thecal equivalent is provided in Table 3. Taxonomy is presented in Appendix 1 (available at: www.int-res.com/journals/suppl/Pospelova_appendix.pdf).

Spiniferites spp. includes all Spiniferites cysts except $S$. bentorii, S. elongatus and $S$. membranaceus. For statistical treatment, species of the genus Brigantedinium (B. cariacoense and B. simplex) were grouped together because cyst-folding or orientation sometimes ob- scured the archeopyle characteristics, thus preventing identification to species level.

Species richness is used in this study as a measure of dinoflagellate cyst diversity (see discussion in Pospelova et al. 2002). To correct for non-equal cyst counts in different samples, Fisher's alpha index is often introduced (Fisher et al. 1943). This is a diversity index, defined for each sample implicitly by the formula:

$$
S=\alpha \cdot \ln (1+n / \alpha)
$$

where $S$ is number of cyst taxa, $n$ is the cyst count and $\alpha$ is Fisher's alpha. All statistical calculations for this work were made using SPSS 10.1 for Windows software.

\section{RESULTS}

\section{Metals, PCBs and organic carbon}

Samples from the inner part of New Bedford Harbor (Group I) had the highest concentrations of all metals (Table 4, Fig. 2), with average concentrations of $\mathrm{Zn}$ of $372 \mu \mathrm{g} \mathrm{g}^{-1}$, Cu of $516 \mu \mathrm{g} \mathrm{g}^{-1}$, and $\mathrm{Pb}$ of $156 \mu \mathrm{g} \mathrm{g}^{-1}$. The concentrations of metals in the outer harbor and Clarks Cove (Group II) are lower, on average, by a factor of 3, with $\mathrm{Zn} 144 \mu \mathrm{g} \mathrm{g}^{-1}, \mathrm{Cu} 55 \mu \mathrm{g} \mathrm{g}^{-1}$, and $\mathrm{Pb} 49 \mu \mathrm{g} \mathrm{g}{ }^{-1}$. Apponagansett Bay (Group III) was characterized by low levels of metals pollution: $\mathrm{Zn} 92 \mathrm{\mu g} \mathrm{g}^{-1}, \mathrm{Cu} 40 \mu \mathrm{g}$ $\mathrm{g}^{-1}$, and $\mathrm{Pb} 23 \mu \mathrm{g} \mathrm{g}^{-1}$. The concentration of PCBs followed the same trend (Table 4$)$, the highest concentrations being in Group I ( 17 $\left.000 \mathrm{ng} \mathrm{g}^{-1}\right)$, moderate con- 


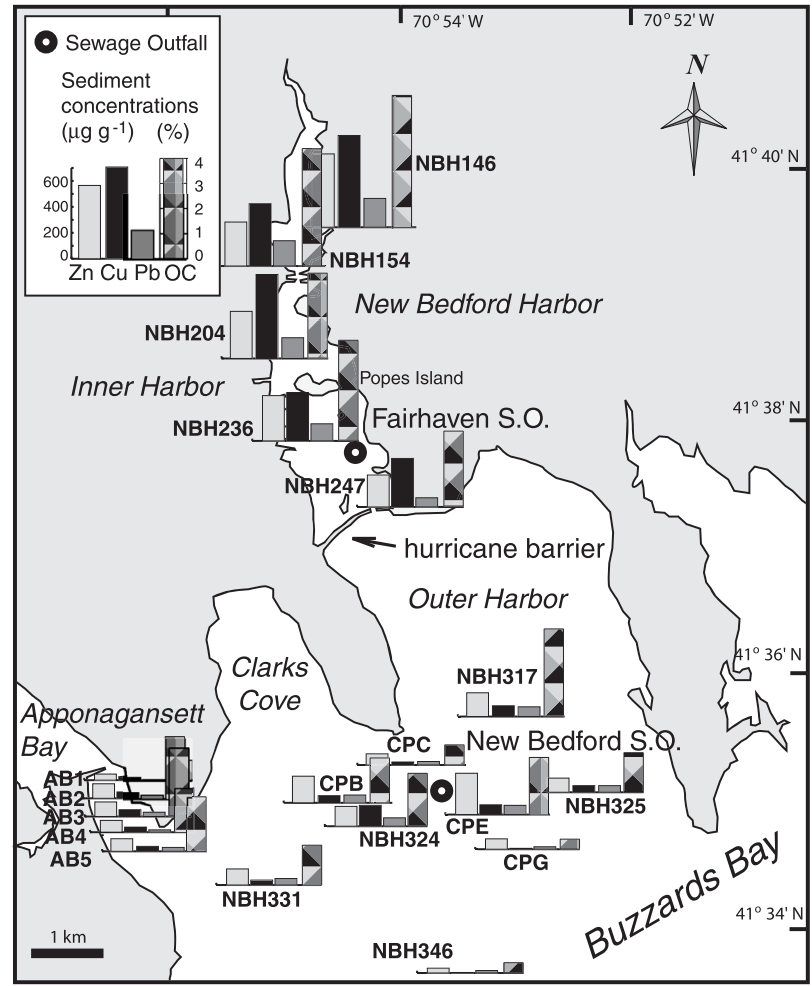

Fig. 2. Distribution of sedimentary concentrations of $\mathrm{Zn}, \mathrm{Cu}$, $\mathrm{Pb}\left(\mu \mathrm{g} \mathrm{g}^{-1}\right)$ and organic carbon $(\mathrm{OC}, \%)$ content in New Bedford Harbor, Clarks Cove and Apponagansett Bay

centrations $\left(\sim 1300 \mathrm{ng} \mathrm{g}^{-1}\right)$ in Group II, and the lowest (500 ng g ${ }^{-1}$ ) in Group III. Organic carbon content (Table 4, Fig. 2) was highest in the inner New Bedford Harbor sediments (3.0 to 5.3\%). Sediment samples from Apponagansett Bay, the outer harbor and Clarks Cove had comparable organic carbon content ranging from 0.4 to $2.7 \%$. Distribution of $\mathrm{Ag}$ and $\mathrm{Cd}$ did not follow the same pattern, as the highest values were found in the outer harbor, near the location of the New Bedford sewage outfall.

We calculated Pearson's correlations to determine the degree of covariance between concentrations of contaminants and content of organic carbon (Table 5). Most correlation coefficients were higher than $0.50(p \leq 0.02)$. Thus, sedimentary concentrations of PCBs, $\mathrm{Zn}, \mathrm{Cu}, \mathrm{Cr}, \mathrm{Pb}, \mathrm{Ni}$, Ag and organic carbon content were highly covariant and the effect of individual pollutants on the system could not be separated.

\section{Distribution of dinoflagellate cysts}

An average of 317 cysts and a minimum of 102 were counted in each sample. We identified and counted 35 dinoflagellate cyst taxa in sediments from 19 sites
Table 3. Taxonomic designation of dinoflagellate cysts counted in this study. Thecal equivalents from Head (1996), except for Islandinium brevispinosum (from Pospelova \& Head 2002) and I. cezare and I. minutum (from Head et al. 2001)

\begin{tabular}{|c|c|}
\hline $\begin{array}{l}\text { Cyst species } \\
\text { (paleontological name) }\end{array}$ & $\begin{array}{l}\text { Dinoflagellate thecate name } \\
\text { or affinity (biological name) }\end{array}$ \\
\hline \multicolumn{2}{|l|}{ Autotrophic } \\
\hline \multicolumn{2}{|l|}{ Gonyaulacaceae } \\
\hline - & Alexandrium tamarense \\
\hline Impagidinium spp. & ? Gonyaulax sp. indet. \\
\hline Lingulodinium machaerophorum & Lingulodinium polyedrum \\
\hline Nematosphaeropsis spp. & Gonyaulax spinifera complex \\
\hline $\begin{array}{l}\text { Operculodinium centrocarpum } \\
\text { sensu Wall \& Dale } 1996\end{array}$ & Protoceratium reticulatum \\
\hline Operculodinium israelianum & ? Protoceratium reticulatum \\
\hline Spiniferites bentorii & Gonyaulax digitalis \\
\hline Spiniferites elongatus & Gonyaulax spinifera complex \\
\hline Spiniferites membranaceus & Gonyaulax spinifera complex \\
\hline Spiniferites spp. & Gonyaulax complex \\
\hline Tectatodinium pellitum & Gonyaulax spinifera complex \\
\hline
\end{tabular}

Peridiniaceae

$-$

Pyrophacaceae

Tuberculodinium vancampoae

Heterotrophic

Diplopsalidaceae

Dubridinium spp.

Gymnodiniales

$-$

Polykrikaceae

$-$

Peridiniaceae

Peridinium wisconsinense

Protoperidiniaceae

Brigantedinium cariacoense

Brigantedinium simplex

Brigantedinium spp.

Islandinium brevispinosum

Islandinium? cezare

Islandinium minutum

Lejeunecysta oliva

Lejeunecysta sabrina

Protoperidinium minutum

Protoperidinium spp.

Quinquecuspis concreta

Selenopemphix nephroides

Selenopemphix quanta

Stelladinium stellatum

Trinovantedinium applanatum

Votadinium calvum

Votadinium spinosun

Pentapharsodinium dalei

Pyrophacus steinii

Diplopsalid group

Gymnodinium spp.

Polykrikos schwartzii Polykrikos kofoidii

Peridinium wisconsinense

Protoperidinium avellanum Protoperidinium conicoides ? Protoperidinium spp.

Protoperidinium sp. indet.

Protoperidinium sp. indet.

Protoperidinium sp. indet.

Protoperidinium sp. indet.

Protoperidinium leonis

Protoperidinium minutum

Protoperidinium sp. indet.

Protoperidinium leonis

Protoperidinium subinerme

Protoperidinium conicum

Protoperidinium stellatum

Protoperidinium pentagonum

Protoperidinium oblongum

Protoperidinium claudicans

(Table 6). Microphotographs of cyst taxa are shown in Figs. 3 to 7.

Dinoflagellate cysts were recovered from all the sediment samples. Total dinoflagellate cyst concentrations varied by an order of magnitude, from $\sim 300$ to 4200 cysts $\mathrm{cm}^{-3}$ and $\sim 500$ to 9400 cysts $\mathrm{g}^{-1}$, averaging $\sim 2000$ cysts $\mathrm{cm}^{-3}$ and $\sim 4300$ cysts $\mathrm{g}^{-1}$ (Tables $7 \& 8$, Fig. 8). In general, the total cyst concentrations in inner 
New Bedford Harbor (Group I) were 2 to 3 times lower compared to the outer harbor and Clarks Cove (Group II) and Apponagansett Bay (Group III). The highest concentrations were found in Group II, which was also characterized by the largest range of variation within the group; the total cyst concentrations ranged from

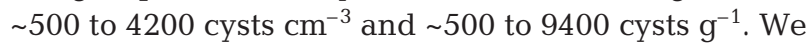
divided the highest by the lowest value for the total cyst concentration within each group to characterize fluctuations in cyst concentrations. These fluctuations can be expressed as a ratio of 6:8:4 for Groups I, II and III if concentrations are expressed in units of cysts per volume of sediments, and as 12:20:7 if cysts per dry weight are used.

The ratio between cysts produced by autotrophic and heterotrophic dinoflagellates ranged from 0.9 to

Table 4. Concentrations of organic carbon (OC, \%), PCBs $\left(\mathrm{ng} \mathrm{g}^{-1}\right)$ and metals $\left(\mu \mathrm{g} \mathrm{g}^{-1}\right)$ in sediments

\begin{tabular}{|c|c|c|c|c|c|c|c|c|c|}
\hline $\begin{array}{c}\text { Group } \\
\text { Site }\end{array}$ & $\mathrm{OC}$ & PCBs & $\mathrm{Zn}$ & $\mathrm{Cu}$ & $\mathrm{Cr}$ & $\mathrm{Pb}$ & $\mathrm{Cd}$ & $\mathrm{Ni}$ & $\mathrm{Ag}$ \\
\hline \multicolumn{10}{|l|}{ Group I } \\
\hline NBH 146 & 5.3 & 33525 & 564.9 & 706.8 & 204.1 & 222.1 & 0.73 & 39.9 & 1.85 \\
\hline NBH154 & 4.7 & 22532 & 339.1 & 480.0 & 249.7 & 194.9 & 1.06 & 38.3 & 4.63 \\
\hline NBH204 & 3.4 & 15052 & 362.7 & 647.0 & 296.2 & 160.2 & 1.39 & 41.5 & 3.02 \\
\hline NBH236 & 4.0 & 10495 & 349.1 & 373.0 & 210.7 & 132.2 & 0.85 & 27.6 & 3.47 \\
\hline NBH247 & 3.0 & 4520 & 245.7 & 374.4 & 122.4 & 71.5 & 0.54 & 11.1 & 2.65 \\
\hline \multicolumn{10}{|l|}{ Group II } \\
\hline NBH324 & 2.1 & 2757 & 153.4 & 161.2 & 121.9 & 64.8 & 0.75 & 29.4 & 2.90 \\
\hline CPE & 2.3 & 1039 & 317.7 & 74.8 & 197.4 & 70.6 & 0.20 & 40.6 & 4.64 \\
\hline CPC & 0.8 & 938 & 85.7 & 22.8 & 39.0 & 27.3 & 0.20 & 7.9 & 0.73 \\
\hline $\mathrm{CPB}$ & 1.8 & 1481 & 205.0 & 55.5 & 92.1 & 60.0 & 0.42 & 24.8 & 2.02 \\
\hline $\mathrm{CPG}$ & 0.4 & 138 & 80.2 & 6.9 & 23.4 & 19.4 & 0.06 & 5.8 & 0.22 \\
\hline NBH317 & 2.5 & 3885 & 183.5 & 83.3 & 111.8 & 75.5 & 0.78 & 20.9 & 4.42 \\
\hline NBH325 & 1.6 & 1205 & 108.7 & 50.6 & 85.3 & 51.0 & 0.24 & 19.4 & 1.36 \\
\hline NBH346 & 0.4 & 61 & 37.3 & 4.2 & 23.4 & 19.2 & 0.10 & 6.6 & 0.14 \\
\hline NBH331 & 1.6 & 729 & 123.7 & 37.7 & 78.4 & 50.4 & 0.41 & 23.9 & 1.15 \\
\hline \multicolumn{10}{|l|}{ Group III } \\
\hline $\mathrm{AB} 1$ & 0.8 & 134 & 47.4 & 19.7 & 34.3 & 5.8 & 0.09 & 3.0 & 0.28 \\
\hline AB2 & 2.5 & 726 & 112.2 & 48.7 & 60.5 & 28.1 & 0.30 & 7.4 & 0.79 \\
\hline AB3 & 2.7 & 537 & 112.5 & 52.4 & 63.5 & 32.6 & 0.18 & 11.2 & 1.03 \\
\hline AB4 & 1.8 & 398 & 90.8 & 39.1 & 54.2 & 18.5 & 0.17 & 5.0 & 0.86 \\
\hline AB5 & 2.2 & 579 & 96.9 & 38.0 & 57.4 & 30.5 & 0.21 & 7.6 & 0.89 \\
\hline
\end{tabular}

Table 5. Correlation matrix of organic carbon, PCBs and metal sedimentary concentrations. Coefficients with $\mathrm{R}>0.5$ and significance at 0.01 level in bold

\begin{tabular}{|lrrrrrrrrr|}
\hline & OC & \multirow{2}{*}{ PCBs } & \multirow{2}{*}{$\mathrm{Zn}$} & $\mathrm{Cu}$ & $\mathrm{Cr}$ & $\mathrm{Pb}$ & $\mathrm{C} d$ & $\mathrm{Ni}$ & $\mathrm{Ag}$ \\
\hline $\mathrm{OC}$ & & $\mathbf{0 . 8 4 9}$ & $\mathbf{0 . 8 7 8}$ & $\mathbf{0 . 8 4 9}$ & $\mathbf{0 . 8 1 1}$ & $\mathbf{0 . 8 9 4}$ & $\mathbf{0 . 7 3 0}$ & $\mathbf{0 . 6 8 7}$ & $\mathbf{0 . 6 1 7}$ \\
$\mathrm{PCBs}$ & $\mathbf{0 . 8 4 9}$ & & $\mathbf{0 . 8 7 9}$ & $\mathbf{0 . 9 1 1}$ & $\mathbf{0 . 7 4 2}$ & $\mathbf{0 . 9 5 2}$ & $\mathbf{0 . 6 8 6}$ & $\mathbf{0 . 6 7 8}$ & 0.411 \\
$\mathrm{Zn}$ & $\mathbf{0 . 8 7 8}$ & $\mathbf{0 . 8 7 9}$ & & $\mathbf{0 . 8 9 1}$ & $\mathbf{0 . 8 7 7}$ & $\mathbf{0 . 9 3 6}$ & $\mathbf{0 . 7 0 5}$ & $\mathbf{0 . 8 3 7}$ & $\mathbf{0 . 6 3 9}$ \\
$\mathrm{Cu}$ & $\mathbf{0 . 8 4 9}$ & $\mathbf{0 . 9 1 1}$ & $\mathbf{0 . 8 9 1}$ & & $\mathbf{0 . 8 5 3}$ & $\mathbf{0 . 9 3 0}$ & $\mathbf{0 . 8 2 0}$ & $\mathbf{0 . 6 9 4}$ & 0.482 \\
$\mathrm{Cr}$ & $\mathbf{0 . 8 1 1}$ & $\mathbf{0 . 7 4 2}$ & $\mathbf{0 . 8 7 7}$ & $\mathbf{0 . 8 5 3}$ & & $\mathbf{0 . 8 9 3}$ & $\mathbf{0 . 8 6 8}$ & $\mathbf{0 . 9 0 0}$ & $\mathbf{0 . 7 8 8}$ \\
$\mathrm{Pb}$ & $\mathbf{0 . 8 9 4}$ & $\mathbf{0 . 9 5 2}$ & $\mathbf{0 . 9 3 6}$ & $\mathbf{0 . 9 3 0}$ & $\mathbf{0 . 8 9 3}$ & & $\mathbf{0 . 8 2 4}$ & $\mathbf{0 . 8 3 3}$ & $\mathbf{0 . 6 2 7}$ \\
$\mathrm{Cd}$ & $\mathbf{0 . 7 3 0}$ & $\mathbf{0 . 6 8 6}$ & $\mathbf{0 . 7 0 5}$ & $\mathbf{0 . 8 2 0}$ & $\mathbf{0 . 8 6 8}$ & $\mathbf{0 . 8 2 4}$ & & $\mathbf{0 . 7 4 5}$ & $\mathbf{0 . 6 9 3}$ \\
$\mathrm{As}$ & 0.306 & -0.011 & 0.259 & -0.006 & 0.245 & 0.143 & $\mathbf{- 0 . 4 6 6}$ & 0.497 & -0.196 \\
$\mathrm{Ni}$ & $\mathbf{0 . 6 8 7}$ & $\mathbf{0 . 6 7 8}$ & $\mathbf{0 . 8 3 7}$ & $\mathbf{0 . 6 9 4}$ & $\mathbf{0 . 9 0 0}$ & $\mathbf{0 . 8 3 3}$ & $\mathbf{0 . 7 4 5}$ & & $\mathbf{0 . 7 6 6}$ \\
$\mathrm{Ag}$ & $\mathbf{0 . 6 1 7}$ & 0.411 & $\mathbf{0 . 6 3 9}$ & 0.482 & $\mathbf{0 . 7 8 8}$ & $\mathbf{0 . 6 2 7}$ & $\mathbf{0 . 6 9 3}$ & $\mathbf{0 . 7 6 6}$ & \\
\hline
\end{tabular}

4.9 , with an average of 2.0 (Table 6). Cysts of autotrophic dinoflagellates usually comprised more than $50 \%$ of the assemblages (Fig. 9), with the exception of 3 sites-CPG, CPB and AB3 (46 to $47 \%$ ). Cysts of heterotrophic dinoflagellates comprised an average of $36 \%$ of each cyst assemblage, ranging from 17 to $53 \%$ (Fig. 9). The proportion of Diplopsalidaceae and Polykrikaceae was $\sim 12 \%$ at all sites (Fig. 9).

A total of 37 dinoflagellate cyst taxa were identified (Table 6). The number of taxa (species richness) in samples ranged from 12 to 26, with an average of 22, and Fisher's index changed from 3.5 to 6.4 (Table 6, Fig. 8). Cyst assemblages in Group I, the inner part of New Bedford Harbor, were characterized by lower diversity (an average species richness of 17, $\alpha=4.5$ ) compared to assemblages in Groups II (24 taxa, $\alpha=5.7$ ) and III (21 taxa, $\alpha=5.2$ ). There were significant $(\mathrm{p}<0.01)$ negative correlations between dinoflagellate cyst species-richness, Fisher's index and sedimentary concentrations of $\mathrm{Cu}, \mathrm{Zn}, \mathrm{Pb}$, PCBs and organic carbon content (Table 7, Fig. 10). A highly significant correlation $(\mathrm{R}=0.91, \mathrm{p}<0.01)$ between species richness and Fisher's alpha showed that the correction for nonuniform cyst counts in different samples was not significant.

The composition of the dinoflagellate cyst assemblages is described with respect to proportions (Table 6) and concentration by volume and dry weight, respectively (Appendices 2 \& 3; www.int-res.com/journals/suppl/ Pospelova_appendix.pdf). The dominant taxa belonged to Gonyaulacaceae, Spiniferites spp. and Operculodinium centrocarpum sensu Wall \& Dale (1966) (Table 6, Fig. 11). Cyst taxa that comprised $>5 \%$ of the assemblages include Protoperidinium spp., Dubridinium spp., Pentapharsodinium dalei, Islandinium brevispinosum, Brigantedinium spp., Polykrikos kofoidii plus $P$. schwartzii, Islandinium minutum and Spiniferites elongatus. At 4 sites, cysts of the toxic bloom-forming Alexandrium tamarense were found in low proportions $(<2 \%)$.

Principal component analysis (PCA) was performed on taxa percentages using Subprogram 10.1 of the Statistical Package for the Social Sciences (SPSS 10.1). The first principal component (PC1) represented $90 \%$ of the 
variance, whereas the second and the third components explained less than 5 and $2 \%$, respectively. Thus, only PC1 was considered for further analyses.

The first principal component (PC1) was distributed in 2 contrasting patterns. It increased from the upper part of New Bedford Harbor seaward towards the hurricane barrier, but decreased from Clarks Cove Point and inner Apponagansett Bay in the seaward direction (Fig. 12). The highest values of PC1 were near the sewage outfalls of Fairhaven and New Bedford Wastewater Treatment Plants, as well as at Site AB1, the sample from the uppermost reach of Apponagansett Bay included in our study. There was a significant $\left(\mathrm{R}^{2}=0.71\right.$ and $\left.\mathrm{p}<0.001\right)$ linear correlation between PC1 scores and the distance to the nearest locations of the sewage outfalls (Fig. 13) for sites from Groups I and II, for which the distance from the point-sources of sewage discharge could be determined. Sites from Group III were not considered, as there is no identified point source of sewage discharge in Apponagansett Bay. Thus, this is a strong indication that PC1 is related to the discharge of sewage enriched with nutrients.

Fig. 11 shows relative abundances of the dinoflagellate cysts taxa that constituted $>1 \%$ of the assemblages. Amongst these taxa, the proportions of Islandinium brevispinosum and Protoperidinium spp. decreased as PC1 increased, i.e. towards the sewage outfalls (Fig. 11), whereas the proportions of cysts of Quinquecuspis concreta, Protoperidinium minutum, Spiniferites elongatus and Cyst Type E tended to increase with
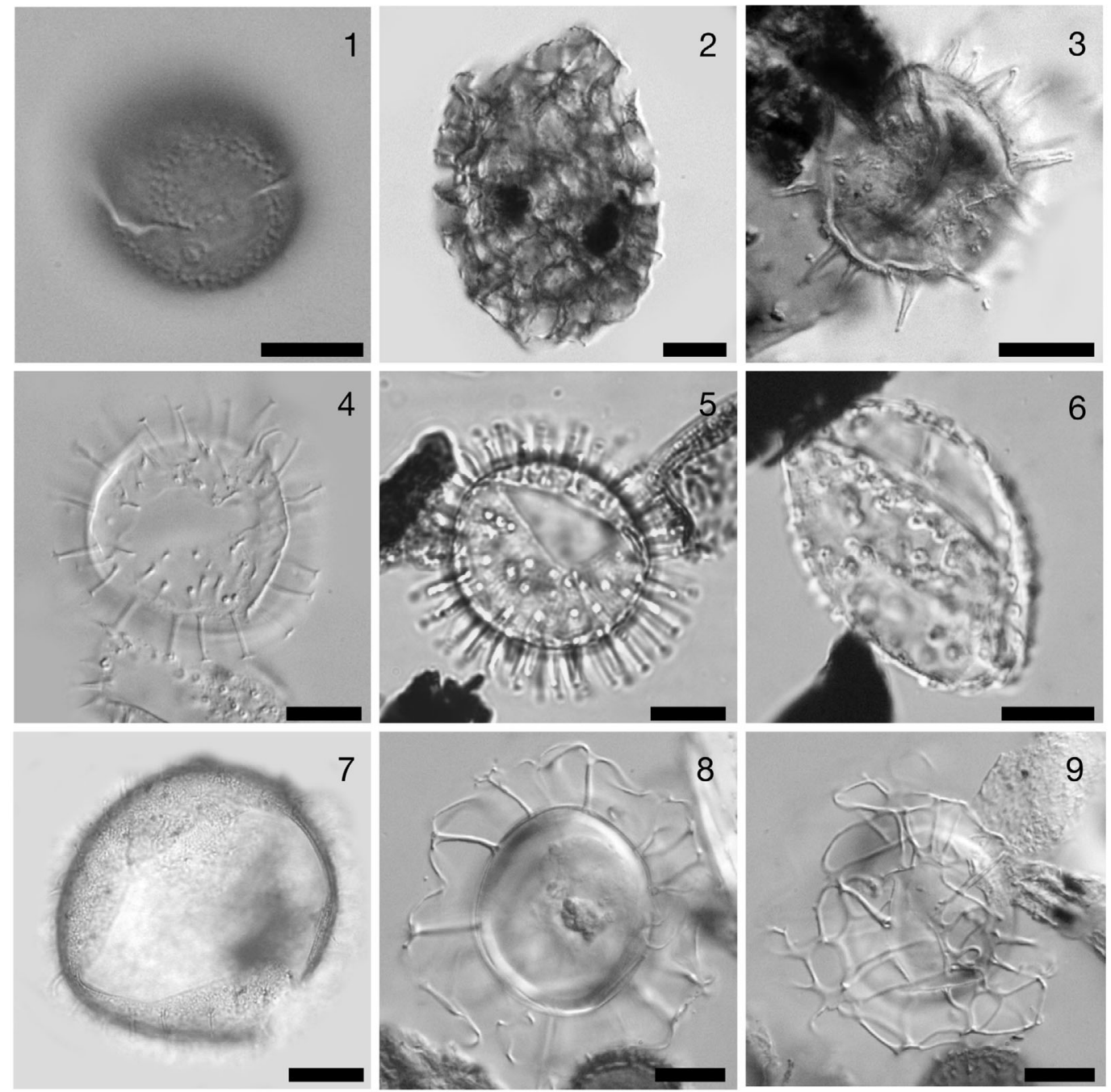

Fig. 3. Bright-field photomicrographs. 1. Gymnodinium spp. indet., NBH325, Slide x, W53/2, lateral surface; 2. Polykrikos schwartzii, NBH346, Slide 1, O29/3, equatorial view; 3. Lingulodinium machaerophorum, NBH247, Slide 1, L391/2, orientation uncertain; 4,5. Operculodinium centrocarpum sensu Wall \& Dale (1966), NBH325, Slide 1, M51/4, dorsal surface (4), and NBH325, Slide 1, dorsal surface (5); 6. Operculodinium centrocarpum var. truncatum, NBH204, Slide 2, S58/3, orientation uncertain; 7. Operculodinium israelianum, AB2, Slide 1, R41/1, dorsal surface; 8,9. Nematosphaeropsis spp. indet, CPE, Slide 1, V38/0, optical section (8), ventral surface (9). Scale bars $=10 \mu \mathrm{m}$ 
increasing PC1. The abundance of Nematosphaeropsis spp. was greater at low $(<0.91)$ and high values of PC1 $(>0.97)$ than at the intermediate values.

\section{DISCUSSION}

Our work documents the composition of dinoflagellate cyst assemblages in surface sediments and studies the cyst distribution on small spatial scales in 3 Buzzards Bay embayments. Spatial variability in cyst concentrations, species diversity and species composition of the assemblages suggest that the cyst assemblages reflect gradients of nutrients and toxic pollution in the embayments. However, prior to discussing the details of these cyst signals, we would like to highlight the complexity of the suggested connection between the dinoflagellate cyst record in the sediments and environmental parameters. Many factors affect the multi-step process from dinoflagellate distribution in estuarine waters to cyst accumulation in sediments. Distribution of dinoflagellate cysts depends on the distribution of dinoflagellates, biological and ecological controls over cyst formation, and hydrographic conditions affecting the cyst deposition in sediments.

Spatial distribution of the motile stage of dinoflagellates is controlled by biotic and abiotic factors. These factors may substantially differ for different groups of dinoflagellates. About half of the dinoflagellates are heterotrophic and half are autotrophic, but some dinoflagellates can feed both ways, termed mixotrophic (Jacobson \& Anderson 1994, Dale 1996). The distribu-
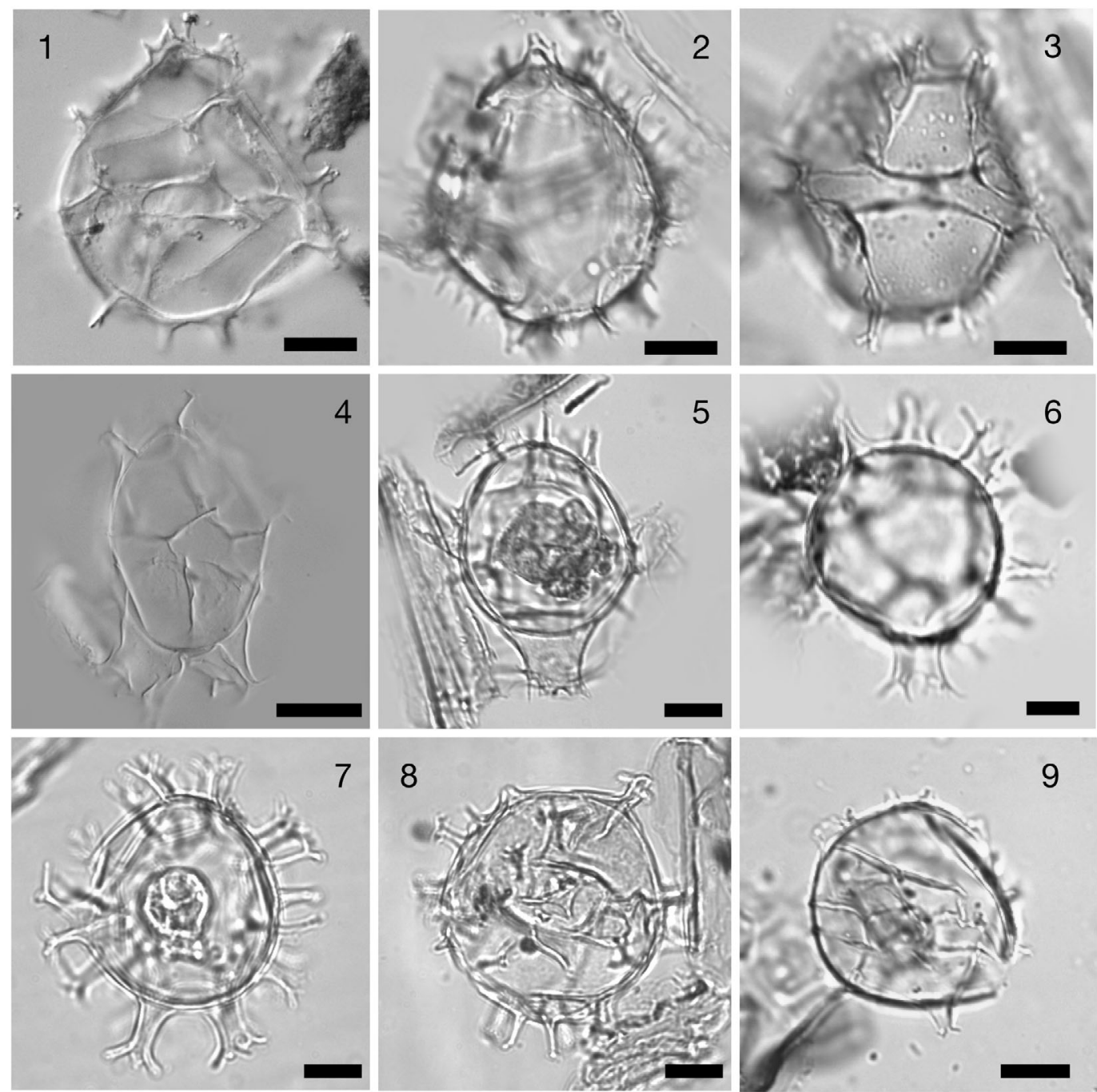

Fig. 4. Bright-field photomicrographs. 1-3. Spiniferites bentorii, CPC, Slide 1, V38/0, lateral surface (1), NBH317, Slide 2, optical section (2), and ventral surface (3); 4. Spiniferites elongatus, NBH325, Slide 1, X36/1, ventral surface; 5,6. Spiniferites membranaceus, NBH236, Slide 1, optical section (5) and AB5, Slide 3, optical section; 7. Spiniferites cf. delicatus, NBH324, Slide 2, optical section; 8,9. Spiniferites spp. indet, NBH325, Slide 1, lateral surface (8) and NBH204, Slide 1, optical section (9). 
tion of heterotrophic dinoflagellates is controlled, in part, by availability of prey (diatoms and small flagellates), whereas the distribution of autotrophic species depends on the availability of light and dissolved nutrients. Both types of dinoflagellates are common in New Bedford Harbor and Apponagansett Bay.

Observations of dinoflagellates in Buzzards Bay by Pierce \& Turner (1994) over a 2 yr period revealed that the stations near the New Bedford Harbor sewage outfalls had significantly (by a factor of 2 to 10) higher dinoflagellate abundance than the other parts of Buzzards Bay. In the same study, significant temporal variability in dinoflagellate abundances caused by seasonal blooms was recorded in New Bedford Harbor. However, high abundances of dinoflagellates may not necessarily be directly reflected in high concentrations of cysts in sedi- ments, because not all species of dinoflagellates are cystproducing, and the process of cyst formation or encystment can also be influenced by environmental factors.

Encystment may happen spontaneously, but also can be enhanced by external factors such as depletion of nutrients - phosphorus and nitrogen in particular (Anderson et al. 1984, Ellegaard et al. 1998), light limitation (Anderson et al. 1985) and other factors. Therefore, high rates of cyst production can reflect high abundances of dinoflagellates and/or enhanced rates of encystment (e.g. caused by depletion of nutrients). However, it is important to note that even in the case of the surface sediments, the cyst record represents many years of deposition, which is approximately $10 \mathrm{yr}$ in the studied embayments. Thus, much of the temporal variability in dinoflagellate abundance and the rate of
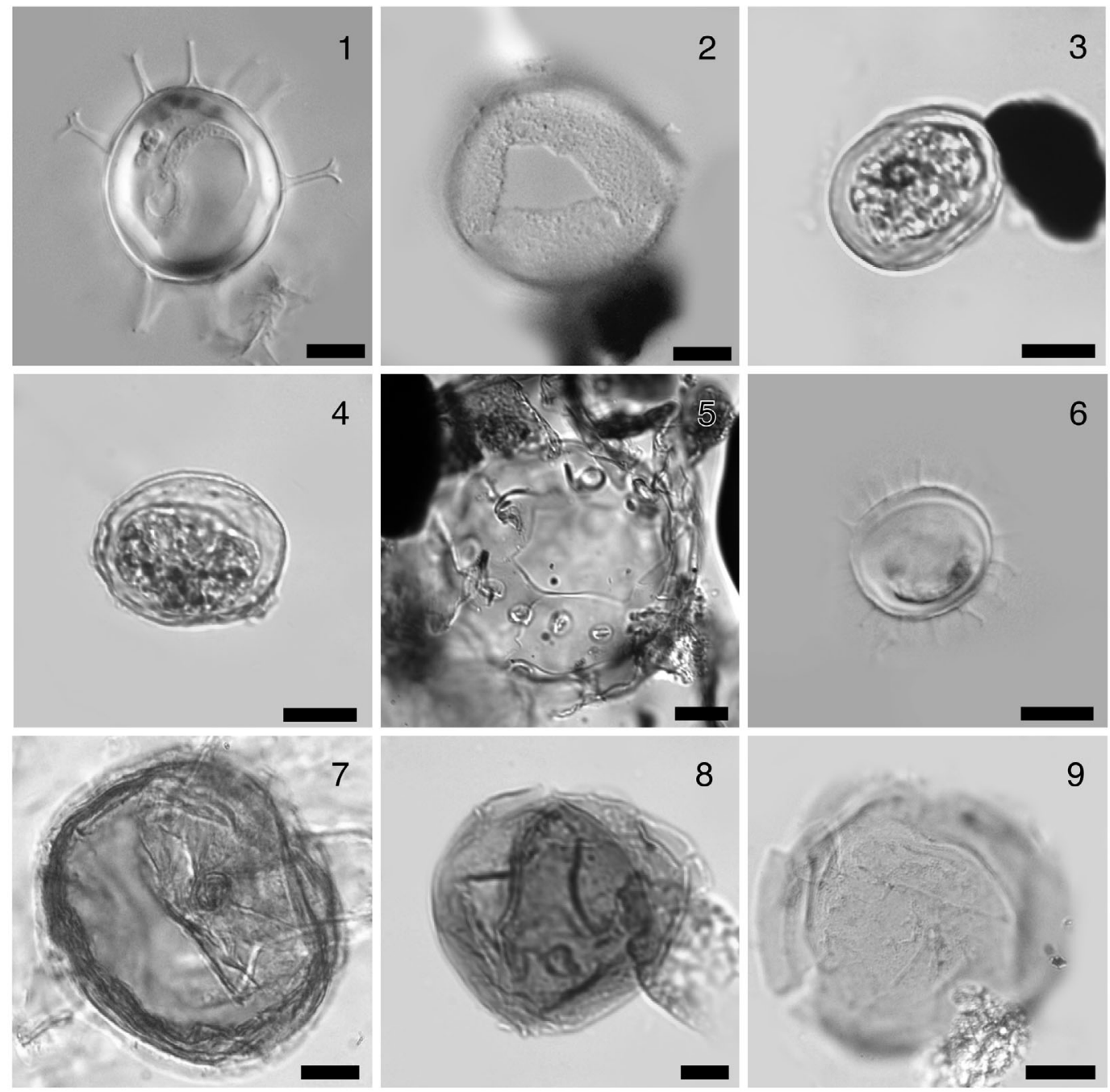

Fig. 5. Bright-field photomicrographs. 1. Spiniferites spp. indet, CPG, Slide 1, optical section; 2. Tectatodinium pellitum, CPE, Slide 1, X48/1, dorsal surface; 3,4. Alexandrium tamarense, NBH247, Slide 1, optical section (3) and NBH247, Slide 2, optical section (4); 5. Tuberculodinium vancampoae, NBH317, Slide 1, T43/1, apical surface; 6. Pentapharsodinium dalei, CPE, Slide 1, F613/4, optical section; 7-9. Dubridinium spp. indet, NBH324, Slide 1, D38/1, apical view (7), CPB, Slide 2, apical surface (8), and NBH236, Slide 4, apical surface (9). Scale bars $=10 \mu \mathrm{m}$ 
encystment average out. At the same time, those environmental factors that are present on the scale of the last 10 yr may be reflected in the 'integrated' sedimentary cyst record. The correlations between dinoflagellate cyst assemblages and environmental parameters found in this study cannot reveal particular mechanisms by which environmental parameters influence the distribution of dinoflagellates and the rates of encystment. To address these mechanisms in details, one would have to tie together the studies of the motile stage of dinoflagellates in the water column, the sediment-trap studies of cyst accumulation, and simultaneous measurements of water-quality parameters (see e.g. Godhe et al. 2001) over an extended period of time. At present, such studies in Buzzards Bay do not appear to be feasible.
Hydrographic regimes in the estuary also affect spatial distribution of dinoflagellate cysts in sediments. When produced, dinoflagellate cysts behave as particles in the water column, and there are several known mechanisms of cyst accumulation in the sediments (see e.g. Harland \& Pudsey 1999). The presence of strong currents may lead to systematic transport of cysts away from the place where they were produced and/or resuspension. In the studied embayments, there are no strong bottom currents, and the influence of the Acushnet River is negligible. Moreover, the inner New Bedford Harbor is almost completely enclosed by a hurricane barrier that restricts water circulation with the rest of the bay. There is no reason to expect that tidal currents in the harbor would transport cysts over significant distances. Hydrographic conditions can be
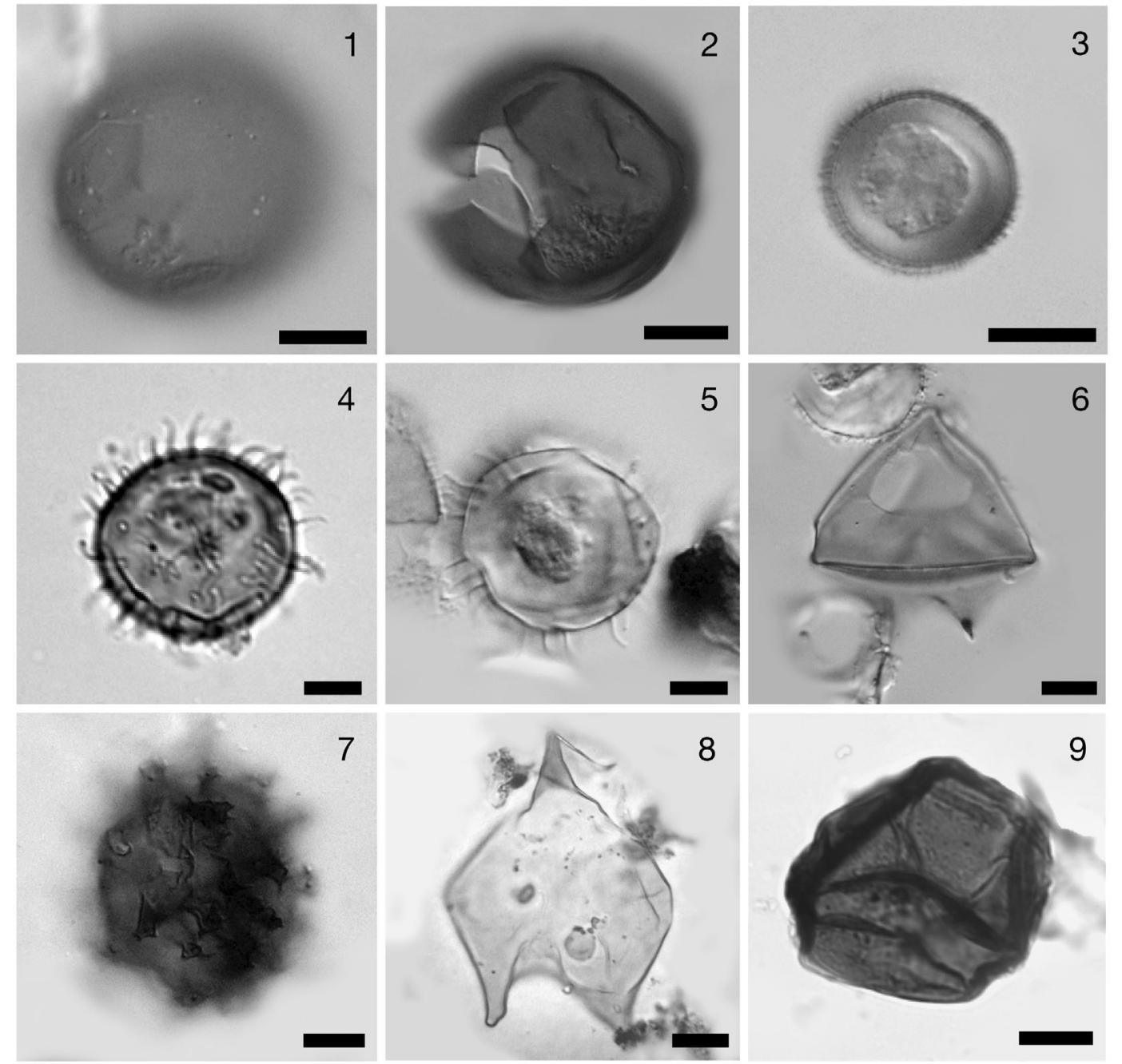

Fig. 6. Bright-field photomicrographs. 1. Brigantedinium cariacoense, CPG, Slide 1, F55/4, lateral surface; 2. Brigantedinium simplex, NBH325, Slide 1, L51/1, dorsal surface; 3. Islandinium brevispinosum, CPG, Slide 1, D48/4, orientation uncertain; 4. Islandinium? cezare, NBH204, Slide 1, orientation uncertain; 5. Islandinium minutum, NBH317, Slide 1, F41/4, optical section; 6. Lejeunecysta oliva, CPC, Slide 1, V56/4, dorsal surface; 7. Protoperidinium minutum, CPE, Slide 1, T46/2, orientation uncertain; 8. Protoperidinium oblongum, CPG, Slide 2, dorsal surface; 9. Protoperidinium spp. indet, NBH325, Slide 2, orientation uncertain. Scale bars $=10 \mu \mathrm{m}$ 
also assessed by studying the spatial distribution of pollutant concentrations in the sediments. High concentrations of metals and other pollutants are found in much greater concentrations near the sources of contamination (in the upper New Bedford Harbor and near the sewage outfalls), suggesting that the sediment transport is not substantial. However, we cannot discount the possibility that effects of short-distance transport are also encoded in our data.

Below we discuss the particular characteristics of the dinoflagellate cyst assemblages in the studied embayments and their relation to environmental conditions, and compare spatial cyst distribution with the temporal cyst records from the sediment cores taken in New Bedford Harbor and Apponagansett Bay (Pospelova et al. 2002).

\section{Total dinoflagellate cyst concentrations}

Despite a number of factors affecting dinoflagellate cyst concentrations in sediments, the total cyst concentration has been regarded as a proxy of dinoflagellate production (e.g. Dale 2001). A potential problem with this approach is that the change in sediment accumulation rate affects dinoflagellate cyst concentrations. In this study, we observe large fluctuations in the total cyst concentrations in the surface sediment samples that could be attributable to varying dinoflagellate production and encystment rates and/or sedimentation rate. However, it is difficult to determine the sedimentation rates station by station. Estimates show that they typically vary between 0.2 and $0.6 \mathrm{~cm} \mathrm{yr}^{-1}$ in the inner New Bedford Harbor and between 0.1 and $0.5 \mathrm{~cm} \mathrm{yr}^{-1}$
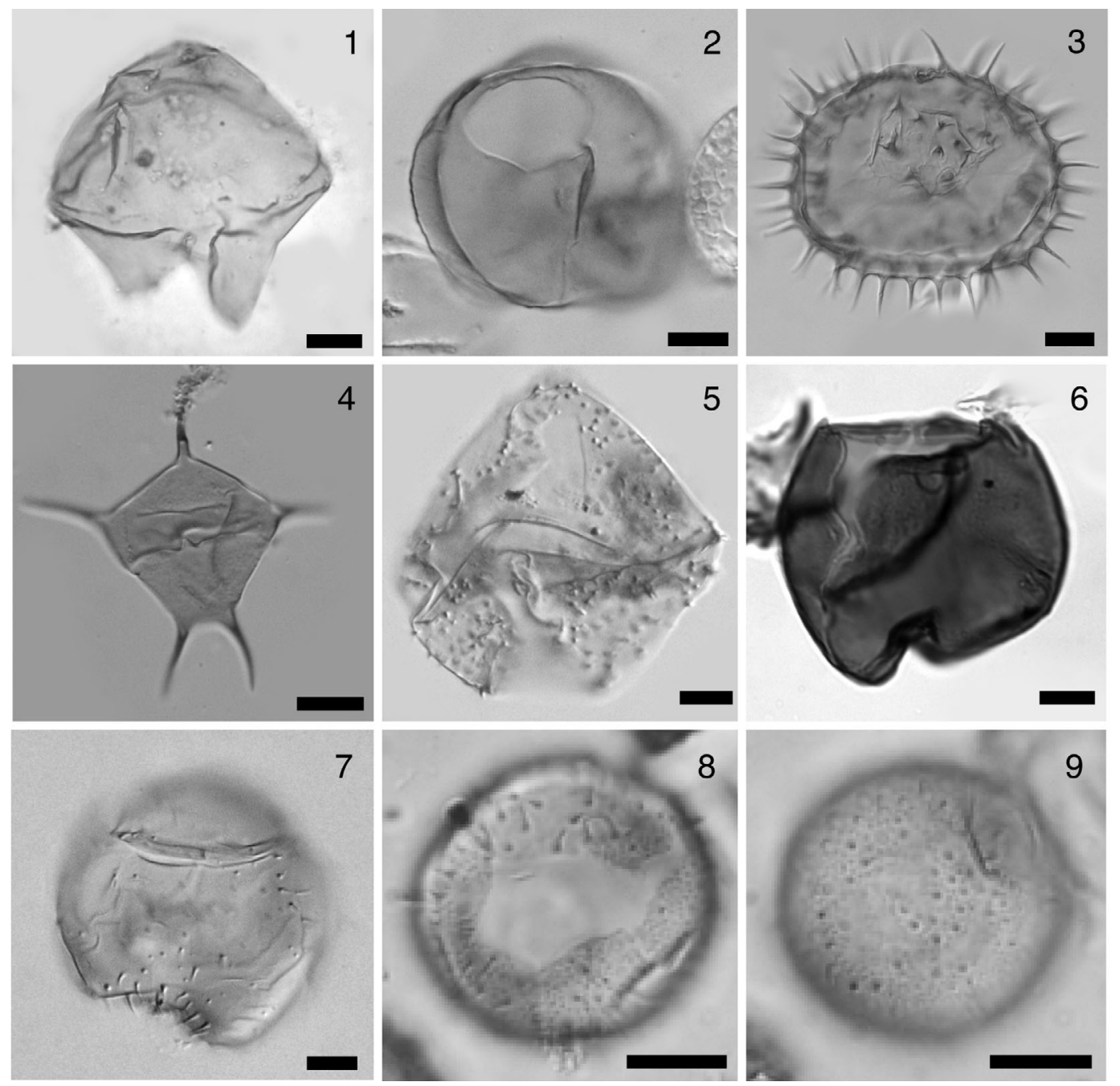

Fig. 7. Bright-field photomicrographs. 1. Quinquecuspis concreta, NBH324, Slide 2, N51/1, ventral surface; 2. Selenopemphix nephroides, CPE, Slide 1, C49/0, apical surface; 3. Selenopemphix quanta, NBH346, Slide 1, X58/4, apical surface; 4. Stelladinium stellatum, CPC, Slide 1, Y59/2, dorsal surface; 5. Trinovantedinium applanatum, CPG, Slide 1, O62/3, dorsal surface; 6. Votadinium calvum, NBH317, Slide 1, dorsal surface; 7. Votadinium spinosum, CPG, Slide 1, O62/3, dorsal surface; 8,9. Cyst type E, CPC, Slide 2, dorsal surface (8), and ventral surface (9). Scale bars $=10 \mu \mathrm{m}$ 


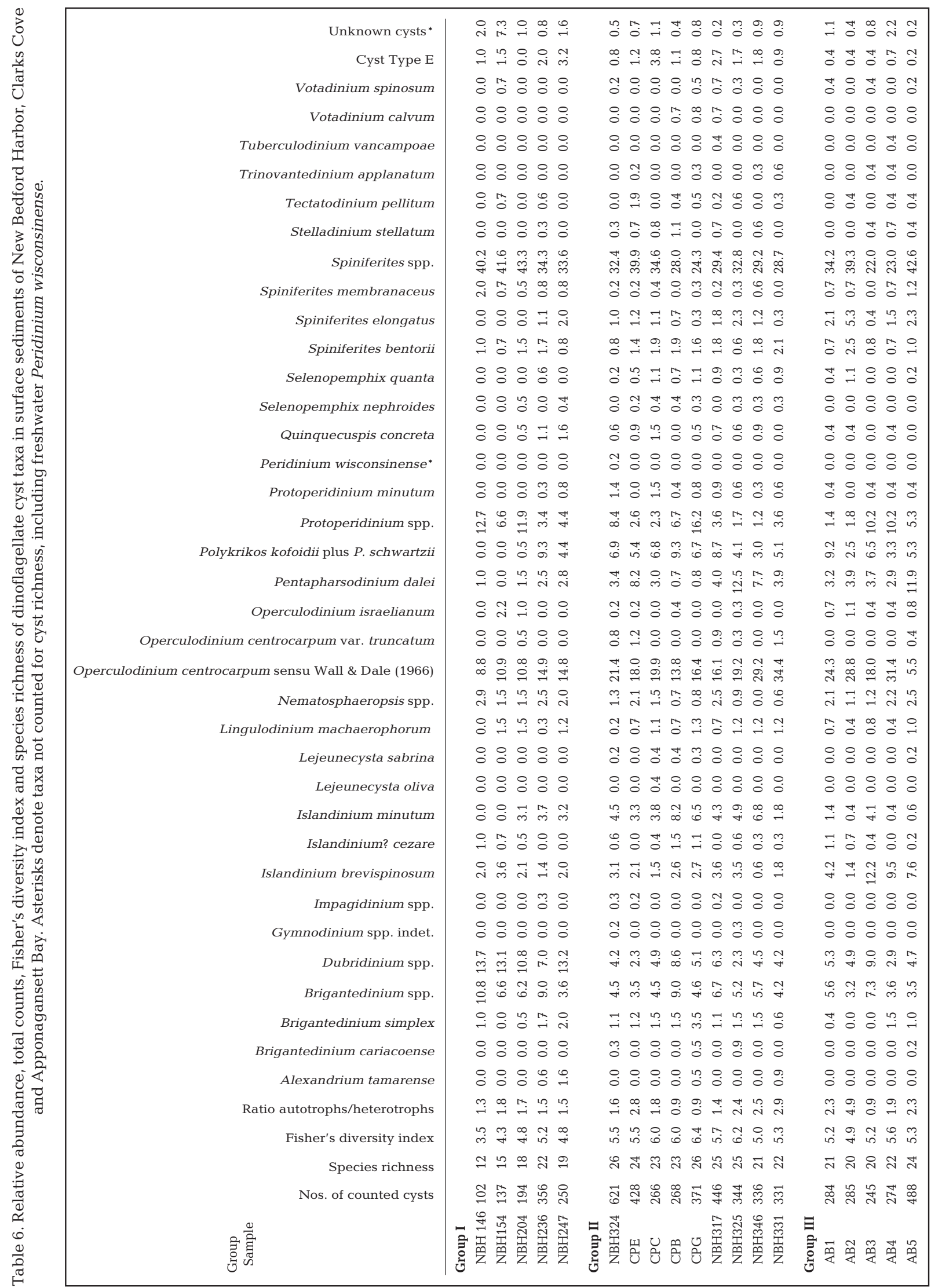




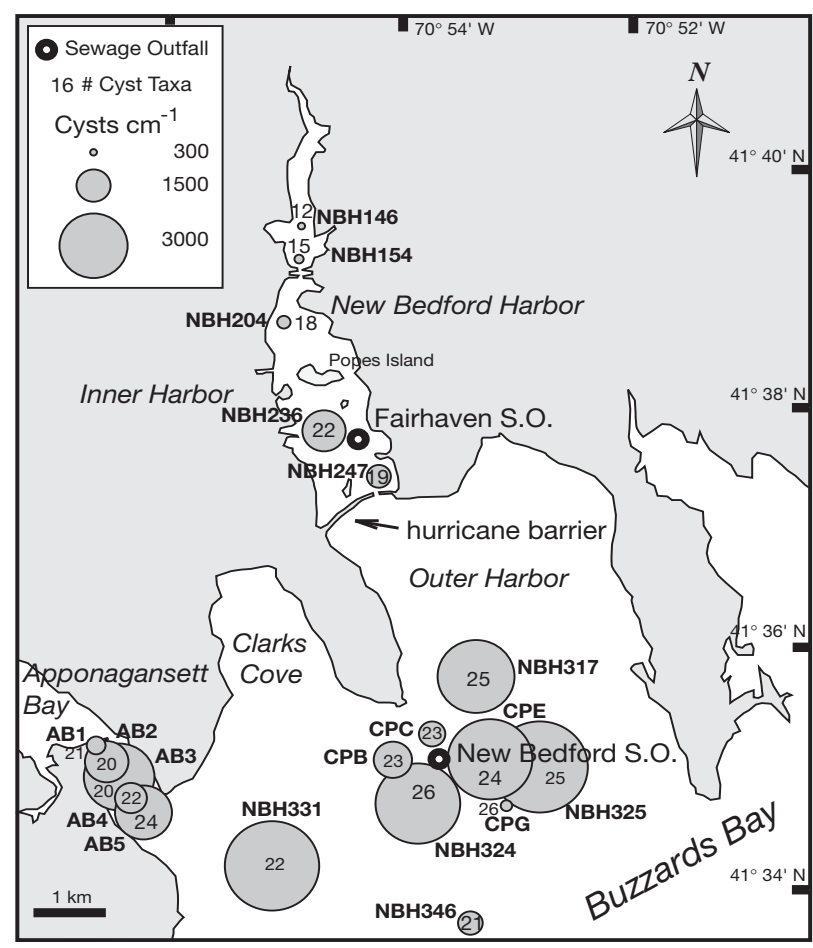

Fig. 8. Distribution of dinoflagellate cyst species-richness and total dinoflagellate cyst concentration in surface sediments of New Bedford Harbor, Clarks Cove and Apponagansett Bay

in the outer harbor, and Apponagansett Bay (Summerhayes et al. 1985, Latimer et al. 2003). Low cyst concentrations $\left(\sim 400\right.$ cysts $\mathrm{cm}^{-3} ; \sim 900$ cysts $\left.\mathrm{g}^{-1}\right)$ in the inner part of New Bedford Harbor, north of the Popes Islands (Sites NBH 146, 154 and 204), are one-fifth those at the other sites, which is probably too large a difference to be explained by variation in the sedimentation rate. Thus the low dinoflagellate cyst concentration in the upper part of inner New Bedford Harbor is likely to be the result of reduced dinoflagellate production. We suggest that the suppressed production is caused by high levels of toxic pollutants in the upper part of inner New Bedford Harbor and possibly by the reduction of the photic zone. Extremely high concentrations of metals and other pollutants found in the sediments indicate toxic water conditions that may affect the dinoflagellate population. Limited light penetration in this part of the harbor was supported by 1 measurement of Secchi depth in August 1993, which showed a very low

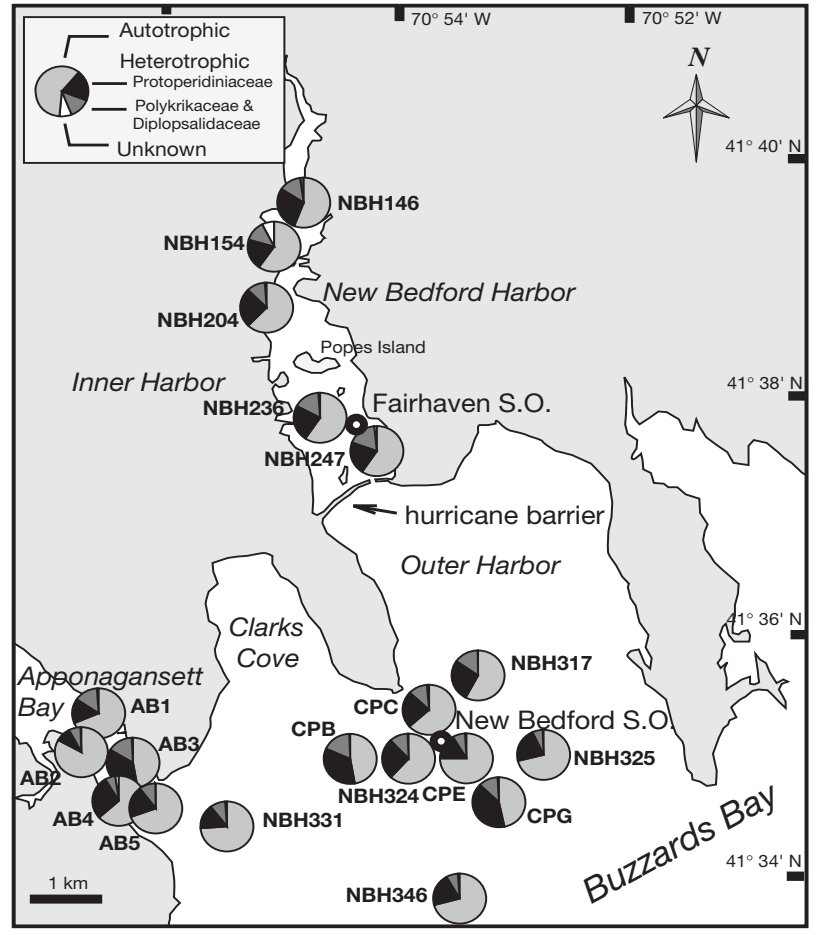

Fig. 9. Relative abundance (\%) of cysts of heterotrophic (Protoperidiniaceae, Polykrikaceae and Diplopsalidaceae) and autotrophic dinoflagellates in assemblages from New Bedford Harbor, Clarks Cove and Apponagansett Bay

value of $0.2 \mathrm{~m}$ (Howes et al. 1999). The reduction of the photic zone may result from high levels of organic carbon in the water column.

\section{Species diversity}

A decline in species richness of phytoplankton has been noted as a possible response to eutrophication (Sommer 1995, Tsirtsis \& Karydis 1998). A decrease in richness of dinoflagellate cyst taxa has been suggested as a general indicator of polluted and highly eutrophic estuarine systems (Pospelova et al. 2002). Sediment samples from the upper part of the inner harbor (Group I) that had lower cyst concentrations also had lower species richness and a lower Fisher index. Species diversity is independent of variation in sedimentation rates and is a more robust indicator

Table 7. Correlation matrix of dinoflagellate cyst species richness (Richness) and the Fisher's diversity index (Fisher's) versus organic carbon, PCBs and metal sedimentary concentrations. Coefficients with R > 0.5 and significance at 0.01 level in bold

\begin{tabular}{|lccccccccccc|}
\hline & $\mathrm{OC}$ & $\mathrm{PCBs}$ & $\mathrm{Zn}$ & $\mathrm{Cu}$ & $\mathrm{Cr}$ & $\mathrm{Pb}$ & $\mathrm{Cd}$ & $\mathrm{Ni}$ & Ag & Richness & Fisher's \\
\hline Richness & $\mathbf{- 0 . 7 1 3}$ & $\mathbf{- 0 . 8 1 3}$ & $\mathbf{- 0 . 6 4 9}$ & $\mathbf{- 0 . 7 6 1}$ & -0.509 & $\mathbf{- 0 . 7 0 4}$ & 0.264 & $\mathbf{- 0 . 4 9 2}$ & 0.190 & \\
Fisher's & $\mathbf{- 0 . 7 5 5}$ & $\mathbf{- 0 . 7 8 3}$ & $\mathbf{- 0 . 6 6 1}$ & $\mathbf{- 0 . 7 5 0}$ & -0.537 & $\mathbf{- 0 . 6 9 6}$ & 0.036 & -0.440 & -0.041 & $\mathbf{0 . 9 1 1}$ & $\mathbf{0 . 9 1 1}$ \\
\hline
\end{tabular}



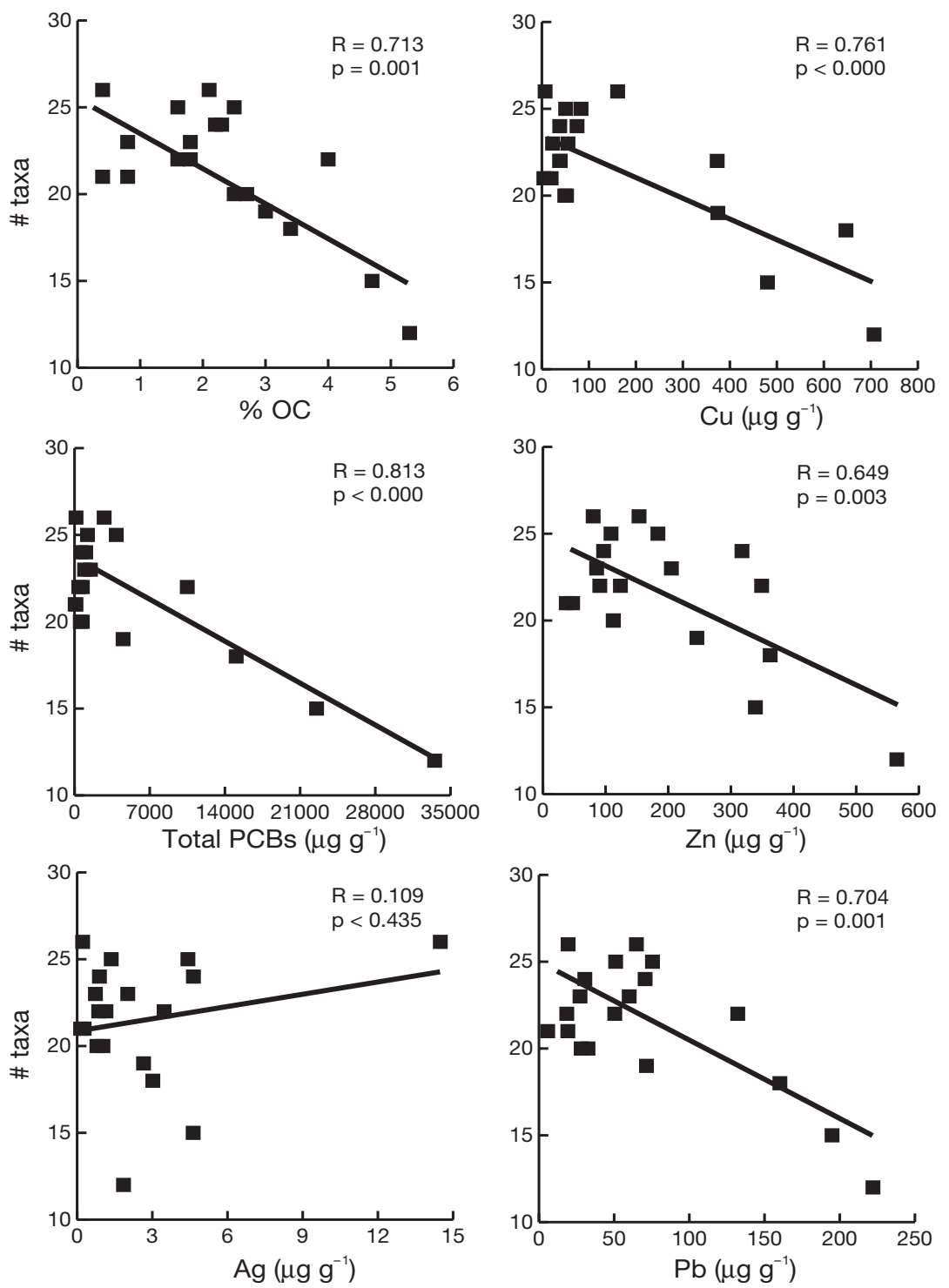

Fig. 10. Relationship between dinoflagellate cyst species-richness and sedimentary concentrations of $\mathrm{Cu}, \mathrm{Zn}, \mathrm{Ag}, \mathrm{Pb}, \mathrm{PCBs}$ and \% organic carbon (OC)

dinoflagellate cysts may be regarded as a combined signal of organic and toxic pollution in the harbor. Further support of this explanation is found in the negative linear relationship between dinoflagellate cyst species-richness and sedimentary concentrations of $\mathrm{Cu}, \mathrm{PCBs}, \mathrm{Zn}$, and $\mathrm{Pb}$, as well as \% organic carbon (OC). Fisher's index shows similar correlations. Although the effects of each constituent may differ, their covariances prevent us from determining more detailed relationships.

\section{Spatial distribution of PCA}

At our study sites, the gradients of salinity and temperature are short compared to those examined in marine and oceanic studies (Wall et al. 1977, Dale 1996, Mudie \& Harland 1996, de Vernal et al. 1997, Rochon et al. 1999). They are also smaller than gradients of temperature and salinity found in the coastal lagoons from the same region (Pospelova et al. 2004). Water temperature and salinity, commonly identified as 2 major factors controlling distribution of dinoflagellate cysts, did not vary with the first principal component in this study. New Bedford Harbor and Apponagansett Bay showed similar patterns, with minor increases in salinity and slight decreases in temperature in the seaward direction, but with opposite trends in the PC1 scores (Fig. 12).

The availability of nutrients has been identified as an important factor controlling the distribution of phytoplankton, and dinoflagellates in particular (Taylor 1987). Unfortunately, there are no data on the concentrations of nitrogen or other nutrients on

that the environmental conditions north of Popes Island are less suitable for dinoflagellate population compared to conditions south of the island. In particular, we found that in the upper part of inner New Bedford Harbor the following cyst taxa were absent or highly suppressed in proportions relative to proportions of the same taxa in the rest of the samples: Spiniferites elongatus, Pentapharsodinium dalei, Polykrikos schwartzii plus P. kofoidii, Islandinium minutum, Protoperidinium minutum. The absence of these species from this part of the harbor is probably due to the same adverse conditions that are responsible for the suppression of the total cyst concentrations e.g. high levels of toxins and hypertrophic conditions. The decrease in Fisher's index and the species richness of the scale of our sample stations. Nevertheless, we can assume that nutrient concentrations decrease with increasing distance from the sewage outfalls.

Previous studies have identified Ag as a marker of sewage effluents (MacKay et al. 1972, Abu-Hilal \& Badran 1990, Bothner et al. 1994). In our study, those sites with high sediment silver-content $\left(\geq 3.5 \mu \mathrm{g} \mathrm{g}^{-1}\right)$ were NBH324, CPE, NBH317, NBH236, and NBH154. Indeed, all these sites except NBH154 are in close proximity to the sewage outfalls and also had the highest PC1 scores based on the proportions of dinoflagellate cysts in the assemblages.

The correlation between PC1 scores and proximity to sewage outfalls (Fig. 13) suggests that PC1 mainly reflects nutrient gradients, and that cyst assemblages 


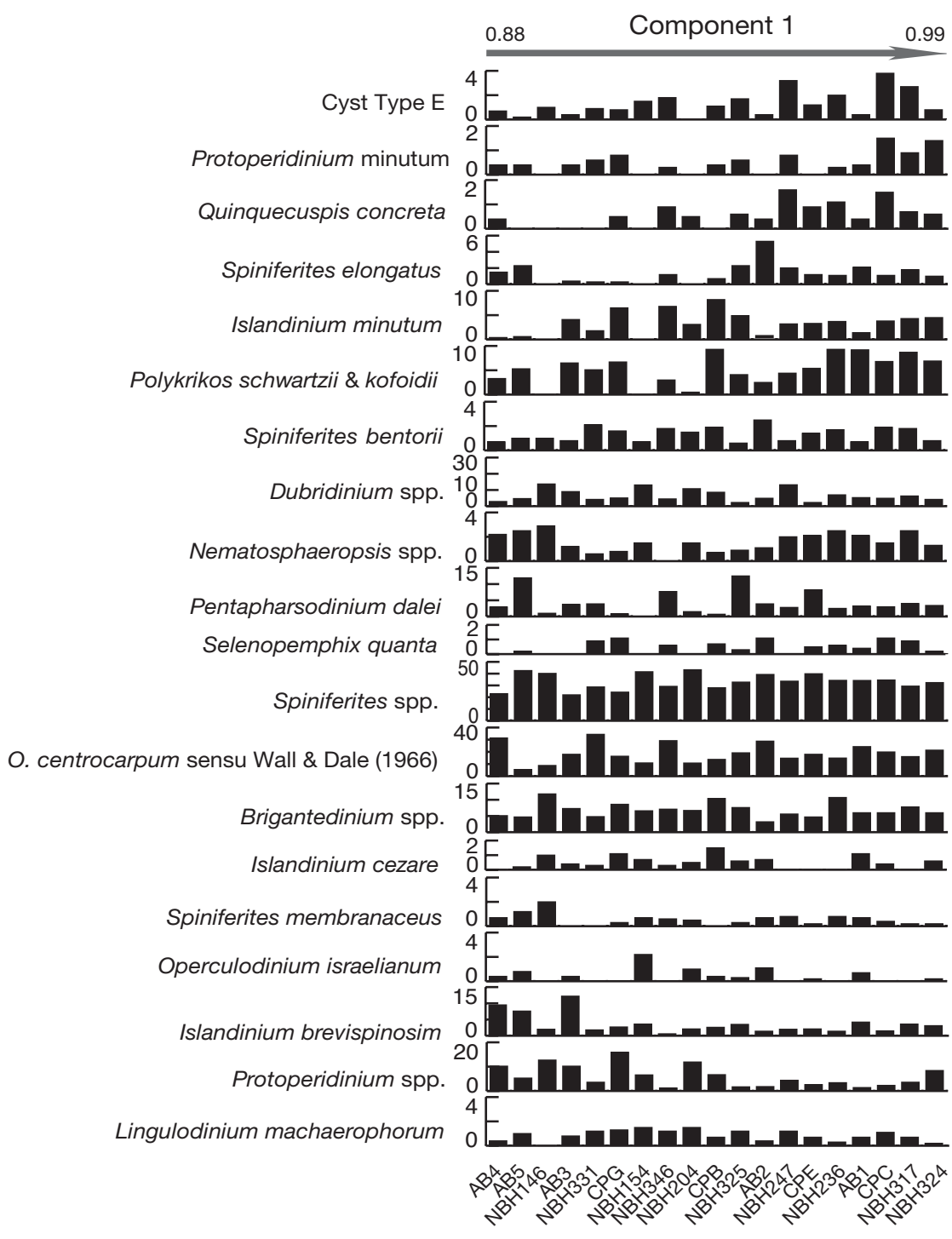

Fig. 11. Proportions of selected dinoflagellate cysts in assemblages from surface sediment samples ordered by first principal component (PC1) of the cores from the same embayments analyzed by Pospelova et al. (2002). Surface and core assemblages have the same ranges for cyst concentration and diversity, and are dominated by the same taxa.

Large fluctuations in the total cyst concentration have been proposed (Pospelova et al. 2002) as a signature of stressed environments. These fluctuations can be seen both in the core and surface assemblages, and the range of the fluctuations in New Bedford Harbor is larger than in Apponagansett Bay. We consider this as a signal of stressed environmental conditions in New Bedford Harbor. However, we understand that a large range of fluctuations in surface sediments is also a reflection of rather large differences in the sediment accumulation rates from site to site as a result of different hydrological conditions.

Another important characteristic of the cyst assemblages in both the temporal and spatial records is the cyst diversity that can be expressed as species richness or Fisher's index. Species richness in the surface samples and in top samples from the cores had similar values. Species richness in the top samples of Core NBH2c from New Bedford Harbor had 15 to 18 taxa (Pospelova et al. 2002) and the closest surface sites (NBH154 and NBH204) in this study had correspondingly 15 and 18 taxa. Top samples from Core AB1c (Apponagansett change with distance from point-sources of nutrient pollution. We infer that dinoflagellate cyst assemblages in Apponagansett Bay also reflect a nutrient signal, because nutrient gradients decrease in the seaward direction (Fig. 12). Since ammonia is the main form of nitrogen from sewage effluent (Borkman \& Turner 1993), it is likely to be a critical parameter affecting the distribution of the dinoflagellate cyst assemblages in the studied embayments.

\section{Comparison of spatial and temporal cyst records}

Dinoflagellate cyst assemblages in surface sediments from New Bedford Harbor and Apponagansett Bay can be compared to the assemblages from the upper parts
Bay) had 21 to 23 taxa, while the surface sites AB4 and AB1 had 22 and 24 taxa. Thus, both in surface and core sediments, species richness in inner New Bedford Harbor is lower than in Apponagansett Bay. Comparison of the Fisher index values reveals the same trend. Similar to temporal records, species richness and the Fisher index were negatively correlated to sedimentary concentrations of toxic metals and organic carbon content. The decrease in species diversity is a response to hypertrophic conditions and/or high levels of inorganic pollutants in the inner part of New Bedford Harbor. The determination of the relative importance of each of these 2 factors on the decline in cyst diversity does not appear to be feasible with the current data set. The increase in species richness in outer Apponagansett Bay was noted as a possible response to eutrophication 


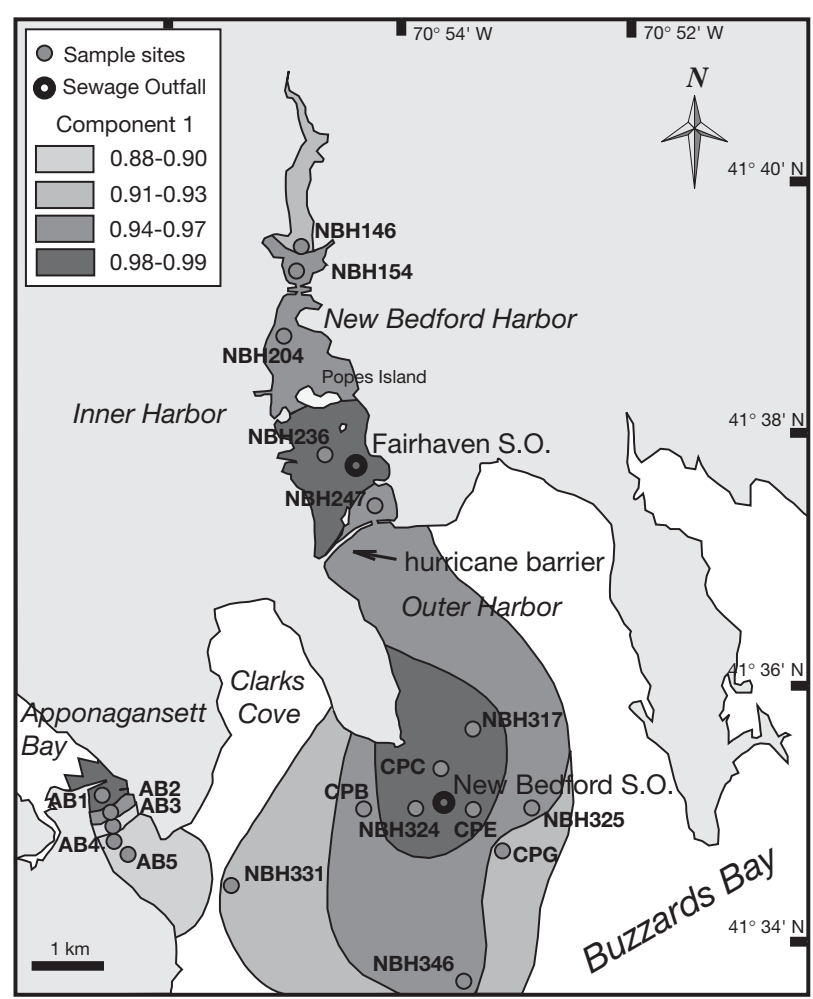

Fig. 12. Spatial distributions of first principal component (PC1) in surface sediments from New Bedford Harbor, Clarks Cove and Apponagansett Bay

when a system changes from oligotrophic/mesotrophic to eutrophic conditions by Pospelova et al. (2002). In surface samples, the highest species richness was recorded in the outer New Bedford Harbor and Apponagansett Bay, which have mesotrophic to eutrophic conditions (Howes et al. 1999).

The increased abundance of cysts of heterotrophic dinoflagellates, particularly Polykrikaceae and Diplopsalidaceae, in temporal records, was seen as a signal of nutrient enrichment of embayment waters by Matsuoka (1999) and Pospelova et al. (2002). Cysts of heterotrophic dinoflagellates constitute a large proportion of the cyst assemblages $(\sim 36 \%)$ in surface sediments, indicating a substantial role of dinoflagellates in modern secondary production. These proportions are twice as high as the maximum abundances of cysts of heterotrophic dinoflagellates that existed in the presettlement period (Pospelova et al. 2002). The abundance of cysts of Polykrikaceae and Diplopsalidaceae remained below $6 \%$ throughout the cores in the study of Pospelova et al. (2002) but exceeded this value in the core sediments accumulated during nutrientenrichment periods. Dinoflagellate cyst assemblages in the surface sediments also contain high (6 to $18 \%$ ) proportions of Polykrikaceae and Diplopsalidaceae cysts, indicating nutrient-rich environments.

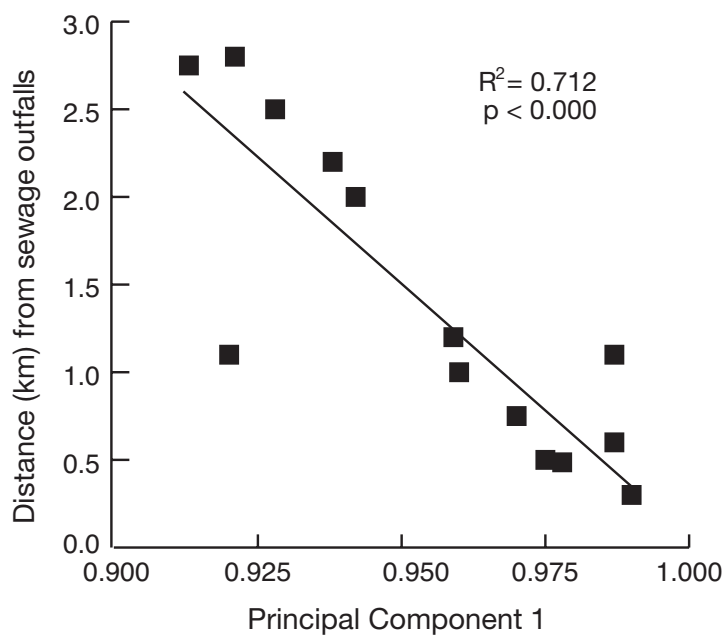

Fig. 13. Relationship between Principal Component 1 and distance from municipal sewage outfalls

Spiniferites spp. seem to be the most tolerant taxa, and they were encountered in high abundances in both studies in the core and surface sediments. Temporal cyst records show that certain rare and common cyst taxa, Dubridinium spp., Islandinium minutum plus I. cezare, Spiniferites bentorii and cysts of Polykrikos schwartzii plus P. kofoidii, increased in abundance with increasing nutrient enrichment as the system shifted from mesotrophic to eutrophic or highly eutrophic conditions (Pospelova et al. 2002). In most surface sediments of New Bedford Harbor, these taxa are present in proportions similar to those observed in sediments concurrent with periods of eutrophication and toxic pollution ( $7 \%$ of Dubridinium spp., $\sim 3 \%$ of I. minutum plus I. cezare, $\sim 1.5 \%$ of $S$. bentorii, and $\sim 5 \%$ of $P$. schwartzii plus $P$. kofoidii). The spatial distribution of cysts of $P$. schwartzii plus $P$. kofoidii showed that these taxa are absent from the most polluted sites in the inner part of New Bedford Harbor. This may indicate that $P$. schwartzii \& kofoidii is suppressed in hypertrophic and highly polluted environments. Temporal studies have shown that Lingulodinium machaerophorum, Operculodinium israelianum and Selenopemphix quanta decline when conditions in the embayments change from oligotrophic to mesotrophic (Pospelova et al. 2002, Chmura et al. 2004); these species were absent or contributed $\leq 1 \%$ to most of the cyst assemblages in surface sites. This does not contradict our temporal studies, since all modern sites have mesotrophic to eutrophic conditions.

To conclude, this study has demonstrated that spatial distribution of dinoflagellate cysts reflects environmental conditions in polluted estuaries. Sites with hypertrophic conditions and the highest levels of toxic pollution were characterized by the lowest dinoflagel- 
late cyst diversity (species richness and Fisher's diversity index), confirming patterns observed in the temporal records. We also found that at small spatial scales, where salinity and temperature variability were low, the distribution of dinoflagellate cysts reflected the proximity to the major sources of nutrient enrichment such as sewage outfalls.

In addition, our study of dinoflagellate cysts from surface sediments revealed dinoflagellate species previously not recorded in the phytoplankton population of Buzzards Bay waters. In this study, we found Gonyaulax digitalis, G. spinifera, Lingulodinium polyedrum, Protoceratium reticulatum, Pentapharsodinium dalei, Polykrikos schwartzii, P. kofoidii, Diplopsalidaceae and multiple species of the Protoperidiniaceae group that have never been reported in previous phytoplankton surveys conducted in Buzzards Bay (Pierce \& Turner 1994, Turner et al. 2000). This underscores the usefulness of studying the dinoflagellate cyst records in sediments as a source of complementary information on phytoplankton composition, especially on species that are either rare and/or have a short motile stage (Dale 1983).

Acknowledgements. We thank the following EPA scientists who have contributed to this research program: S. Nelson, C. Pesch, B. Bergen, and C. Strobel and J. King (University of Rhode Island) for help in collecting sediment samples. V. Pospelova also thanks M. J. Head and A. de Vernal for useful discussions on the taxonomy of dinoflagellate cysts. R. Harland, B. Dale and 3 anonymous reviewers are greatly acknowledged for critically reading the manuscript and giving many valuable suggestions. We thank the Centre de Recherche en Géochimie Isotopique et en Géochronologie (GEOTOP), Université du Québec à Montréal, for technical support. We are grateful to R. Lam and L. Sum for technical assistance. Support for this research was provided by the Natural Sciences and Engineering Research Council of Canada (NSERC) and the Fonds pour la Formation de Chercheurs et l'aide à la Recherche (FCAR) of Quebec.

\section{LITERATURE CITED}

Abu-Hilal AH, Badran MM (1990) Effect of pollution sources on metal concentrations in sediment cores from the Gulf of Aqaba (Red Sea). Mar Pollut Bull 21:190-197

Anderson DM, Kulis DM, Binder BJ (1984) Sexuality and cyst formation in the dinoflagellate Gonyaulax tamarensis: cyst yield in batch culture. J Phycol 20:418-425

Anderson DM, Coats DW, Tyler MA (1985) Encystment of the dinoflagellate Gyrodinium uncatenatum: temperature and nutrient effects. J Phycol 21:200-206

Bergen BJ, Rahn KA, Nelson WG (1998) Remediation at a marine superfund site: surficial sediment PCB congener concentration, composition, and redistribution. Environ Sci Technol 32:3496-3501

Borkman DG, Turner JT (1993) Plankton studies in Buzzards Bay, Massachusetts, USA. II. Nutrients, chlorophyll $a$ and phaeopigments, 1987 to 1990. Mar Ecol Prog Ser 100: $27-34$
Bothner MH, Takada H, Knight I, Hill RT, Butman B, Farrington JW, Colwell RR, Grassle JF (1994) Sewage contamination in sediments beneath a deep-ocean dumpsite off New York. Mar Environ Res 38:43-59

Chmura GL, Santos A, Pospelova V, Spasojevic Z, Lam R, Latimer JS (2004) Response of three palaeo-primary production proxy measures to development of an urban estuary. Sci Tot Environ 320:225-243

Costa JE, Howes BL, Gunn E (1996) Report of the Buzzards Bay citizens' water quality monitoring program 19921995. Buzzards Bay Project, National Estuary Program, Marion, MA

Costa JE, Howes BL, Janik D, Aubrey D, Gunn E, Giblin AE (1999) Managing anthropogenic nitrogen inputs to coastal embayments: technical basis and evaluation of a management strategy adopted for Buzzards Bay. Buzzards Bay Project Technical Report, Buzzards Bay Project, National Estuary Program, Marion, MA

Dale B (1976) Cyst formation, sedimentation, and preservation: factors affecting dinoflagellate assemblages in recent sediments from Trondheimfjord, Norway. Rev Paleobot Palynol 22:39-60

Dale B (1983) Dinoflagellate resting cysts: 'benthic plankton'. In: Fryxell GA (ed) Survival strategies of the algae. Cambridge University Press, Cambridge, p 69-136

Dale B (1996) Dinoflagellate cyst ecology: modeling and geological applications. In: Jansonius J, McGregor DC (eds) Palynology: principles and applications. American Association of Stratigraphic Palynologists Foundation, College Station, TX, p 249-1275

Dale B (2001) Marine dinoflagellate cysts as indicators of eutrophication and industrial pollution: a discussion. Sci Total Environ 264:235-240

Dale B, Fjellså A (1994) Dinoflagellate cysts as productivity indicators: state of the art, potential and limits. In: Zahn R (ed) Carbon cycling in the glacial ocean: constraints in the ocean's role in global change. Springer-Verlag, Berlin, p 521-537

Dale B, Thorsen TA, Fjellså A (1999) Dinoflagellate cysts as indicators of cultural eutrophication in the Oslofjord, Norway. Estuar Coast Shelf Sci 48(3):371-382

de Vernal A, Rochon A, Turon JL, Matthienssen J (1997) Organic-walled dinoflagellate cysts: palynological tracers of sea-surface conditions in middle to high latitude marine environments. Geobios (Villeurbanne) 30:905-920

Ellegaard M, Kulis DM, Anderson DM (1998) Cysts of Danish Gymnodinium nolleri Ellegaard et Moestrup sp. ined. (Dinophyceae): studies on encystment, excystment and toxicity. J Plankton Res 20:1743-1755

Fensome RA, Taylor FJR, Norris G, Sarjeant WAS, Wharton DI, Williams GL (1993) A classification of living and fossil dinoflagellates. Micropaleontology (Spec Publ) 7:1-351

Fensome RA, Riding JB, Taylor FJR (1996) Dinoflagellates. In: Jansonius J, McGregor DC (eds) Palynology: principles and applications. American Association of Stratigraphic Palynologists Foundation, College Station, TX, p 107-170

Fisher RA, Corbet AS, Williams CB (1943) The relation between the number of species and the number of individuals in a random sample of an animal population. J Anim Ecol 12:42-58

Gibson GR, Bowman ML Gerritsen J, Snyder BD (2000) Estuarine and coastal marine waters: bioassessment and biocriteria technical guidance. EPA 822-B-00-024, US Environmental Protection Agency, Office of Water, Washington, DC

Godhe A, Norén F, Kuylenstierna M, Ekberg C, Karlson B (2001) Relationship between planktonic dinoflagellate 
abundance, cysts recovered in sediment traps and environmental factors in the Gullmar Fjord, Sweden. J Plankton Res 23:923-938

Harland R, Pudsey CJ (1999) Dinoflagellate cysts from sediment traps deployed in the Bellingshausen, Weddell and Scotia seas, Antarctica. Mar Micropaleontol 37:77-99

Head MJ (1996) Modern dinoflagellate cysts and their biological affinities. In: Jansonius J, McGregor DC (eds) Palynology: principles and applications. American Association of Stratigraphic Palynologists Foundation, College Station, TX, p 1197-1248

Head MJ, Harland R, Matthiessen J (2001) Cold marine indicators of the late Quaternary: the new dinoflagellate cyst genus Islandinium and related morphotypes. J Quat Sci 16:621-636

Howes BL, Goehringer DD (1996) Ecology of Buzzards Bay: an estuarine profile. National Biological Service Biol Rep 31, National Wetlands Research Center, US Geological Survey, Washington, DC

Howes BL, Williams T, Rasmussen M (1999) Baywatchers II. Nutrient related water quality of Buzzards Bay embayments: a synthesis of baywatchers monitoring 1992-1998. The Coalition for Buzzards Bay, New Bedford, MA

Jacobson DM, Anderson DM (1994) The discovery of mixotrophy in photosynthetic species of Dinophysis (Dinophyceae): light and electron microscopic oberservations of food vacuoles in Dinophysis acuminata, D. norvegica and two heterotrophic dinophysoid dinoflagellates. Phycologia 33:97-110

Latimer JS, Boothman BS, Pesch C, Chmura GL, Pospelova V, Jayaraman J (2003) Environmental stress and recovery: the geochemical record of human disturbance in New Bedford Harbor and Apponagansett Bay, Massachusetts (USA). Sci Total Environ 313:153-176

Lentin JK, Williams GL (1993) Fossil dinoflagellates: index to genera and species. Contribution Series 28, American Association of Stratigraphic Palynologists, College Station, TX

MacKay DW, Halcrow W, Thornton I (1972) Sludge dumping in the Firth of Clyde. Mar Pollut Bull 3:7-10

Matsuoka K (1999) Eutrophication process recorded in dinoflagellate cyst assemblages - a case of Yokohama Port, Tokyo Bay, Japan. Sci Total Environ 231:17-35

Matsuoka K (2001) Further evidence for a marine dinoflagellate cyst as an indicator of eutrophication in Yokohama Port, Tokyo Bay, Japan. Comments on a discussion by B. Dale. Sci Total Environ 264:221-233

Mudie PJ, Harland R (1996) Aquatic Quaternary. In: Jansonius J, McGregor DC (eds) Palynology: principles and applications. American Association of Stratigraphic Palynologists Foundation, College Station, TX, p 843-877

Nelson WG, Bergen BJ, Benyi SJ, Morrison G and 5 others (1996) New Bedford Harbor long-term monitoring assessment report: baseline sampling. Technical Report EPA/600/R-96/097, US Environmental Protection Agency, National Health and Environmental Effects Research Laboratory, Atlantic Ecology Division, Narragansett, RI

Nixon SW (1995) Coastal marine eutrophication: a definition, social causes, and future concerns. Ophelia 41:199-219

Pierce RW, Turner JT (1994) Plankton studies in Buzzards Bay, Massachusetts, USA. III. Dinoflagellates, 1987-1988. Mar Ecol Prog Ser 112:225-234

Pospelova V, Head MJ (2002) Islandinium brevispinosum sp. nov. (Dinoflagellata), a new organic-walled dinoflagellate

Editorial responsibility: Gareth Harding (Contributing Editor), Dartmouth, Canada cyst from modern estuarine sediments of New England (USA). J Phycol 38:593-601

Pospelova V, Chmura GL, Boothman WS, Latimer JS (2002) Dinoflagellate cyst records and human disturbance in two neighboring estuaries, New Bedford Harbor and Apponagansett Bay, Massachusetts (USA). Sci Total Environ 298: 81-102

Pospelova V, Chmura GL, Walker HA (2004) Environmental factors influencing the spatial distribution of dinoflagellate cyst assemblages in shallow lagoons of Southern New England (USA). Rev Paleabot Palynol 128:7-34

Reid PC, Harland R (1978) Studies of Quaternary dinoflagellate cysts from the North Atlantic, Contribution Series 5(A). American Association of Stratigraphic Palynologists, College Station, TX, p 147-169

Rochon A, de Vernal A, Turon JL, Matthiessen J, Head MJ (1999) Distribution of recent dinoflagellate cysts in surface sediments from the North Atlantic Ocean and adjacent seas in relation to sea-surface parameters. Contribution Series 35, American Association of Stratigraphic Palynologists, College Station, TX

SAIC (Science Applications International Corporation) (1991) Characterization of pollutant inputs to Buzzards Bay. Report to US Environmental Protection Agency \& Buzzards Bay Project. Lloyd Center for Environmental Studies, South Dartmouth, MA

Sætre MML, Dale B, Abdullah MI, Sætre GPO (1997) Dinoflagellate cysts as potential indicators of industrial pollution in a Norwegian fjord. Mar Environ Res 44:167-189

Sommer U (1995) An experimental test of the intermediate disturbance hypothesis using cultures of marine phytoplankton. Limnol Oceanogr 40:1272-1277

Stockmarr J (1977) Tablets with spores used in absolute pollen analysis. Pollen Spores 13:615-621

Summerhayes CP, Ellis JP, Stoffers P (1985) Estuaries as sinks for sediment and industrial waste - a case history from the Massachusetts coast. In: Fuchtbauer H, Lisitzin AP, Milliman JD, Siebold E (eds) Contribution to sedimentology. Schweizerbart'sche Verlagsbuchhandlung, Stuttgart

Taylor FGR (1987) Ecology of dinoflagellates. In: Taylor FGR (ed) The biology of dinoflagellates. Bot Monogr 21: 399-529

Terkla DG, Doeringer PB, Teal JM, Howes BL, Evans C, Bluffstone, Weiskel P (1990) Economic growth and environmental change in Buzzards Bay. Jessie B. Cox Charitable Trust, Boston, MA

Thorsen TA, Dale B (1997) Dinoflagellate cysts as indicators of pollution and past climate in a Norwegian fjord. The Holocene 7:433-446

Tsirtsis G, Karydis M (1998) Evaluation of phytoplankton community indices for determining eutrophic trends in the marine environment. Environ Monit Assess 50:255-269

Turner JT, Lincoln JA, Borkman DG, Gauthier DA, Kieser J, Dunn CA (2000) Nutrients, eutrophication and harmful algal blooms in Buzzards Bay, Massachusetts. Final Report, Project 99-03/MWI. Massachusetts Department of Environmental Protection, Boston, MA

Wall D, Dale B (1966) 'Living fossils' in western Atlantic plankton. Nature 211:1125-1126

Wall D, Dale B, Lohmann GP, Smith WK (1977) The environmental and climatic distribution of dinoflagellate cysts in modern marine sediments from regions in the North and South Atlantic Oceans and adjacent seas. Mar Micropaleontol 2:121-200

Submitted: June 13, 2003; Accepted: November 10, 2004

Proofs received from author(s): March 23, 2005 